\title{
High-frequency observations from a deep-sea cabled observatory reveal seasonal overwintering of Neocalanus spp. in Barkley Canyon, NE Pacific: Insights into particulate organic carbon flux
}

\author{
Fabio Cabrera De Leo ${ }^{\mathrm{a}, \mathrm{b}, *}$, Bruno Ogata ${ }^{\mathrm{b}, \mathrm{c}}$, Akash R. Sastri ${ }^{\mathrm{a}, \mathrm{b}}$, Martin Heesemann ${ }^{\mathrm{a}, \mathrm{d}}$, \\ Steven Mihály ${ }^{\mathrm{a}, \mathrm{e}}$, Moira Galbraith ${ }^{\mathrm{e}}$, Michael G. Morley ${ }^{\mathrm{a}}$ \\ ${ }^{a}$ Ocean Networks Canada, University of Victoria, PO Box 1700 STN CSC, Victoria, BC V8W 2Y2, Canada \\ ${ }^{\mathrm{b}}$ Department of Biology, University of Victoria, PO Box 3080, Victoria, BC V8W 2Y2, Canada \\ ${ }^{\mathrm{c}}$ Biosciences Institute, São Paulo State University (UNESP), Coastal Campus, Praça Infante Dom Henrique s/n ${ }^{\circ}$, São Vicente, SP $11330-900$, Brazil \\ ${ }^{\mathrm{d}}$ School of Earth and Ocean Sciences, University of Victoria, PO Box 3080, Victoria, BC V8W 2Y2, Canada \\ ${ }^{\mathrm{e}}$ Institute of Ocean Sciences, Department of Fisheries and Oceans, 9860 W Saanich Rd, Sidney, BC V8L 5T5, Canada
}

\section{A R T I C L E I N F O}

\section{Keywords:}

Barkley Canyon

NE Pacific

NEPTUNE cabled observatory

Neocalanus plumchrus

Overwintering

Zooplankton

Life history

Carbon flux

\begin{abstract}
A B S T R A C T
Many submarine canyons are known hotspots of pelagic and benthic biodiversity and productivity. Despite a very limited knowledge of the ecology, biodiversity and ecosystem function of Canada's West Coast canyons, Barkley Canyon is becoming a relatively well studied system, particularly after the installation of the NEPTUNE seafloor cabled observatory in 2009. Video observations of large densities of overwintering calanoid copepods (likely a combination of Neocalanus plumchrus, $N$. cristatus, and a small contribution of $N$. flemingeri) drifting near the bottom at $970 \mathrm{~m}$ in the axis of Barkley Canyon motivated our interest in investigating the temporal dynamics of their ontogenetic migration cycle. Particularly, since these large calanoid copepods, and especially Neocalanus plumchrus, comprise up to $50 \%$ of of the mesozooplankton biomass in the subarctic NE Pacific, being considered a keystone species in the trophodynamics of pelagic ecosystems in the region. Here we used $\sim 20$-months (May 2013-Jan 2015) of seafloor video imagery combined with acoustic Doppler current and backscatter time-series data from the NEPTUNE observatory to identify the precise timing and seasonal and inter-annual variability in the deep ontogenetic migration of Neocalanus spp. in Barkley Canyon. A total of 33,486 still images were extracted from $1674 \times 5$-min segment videos, captured at two-hour intervals, and used in a computer-automated image analysis protocol designed to estimate Neocalanus spp. densities near the seafloor. The results from the entire time-series revealed close correspondence with the described developmental and reproductive cycle for Neocalanus spp., with the highest densities of copepodite-5 (C5) and adult individuals present at depth from the late fall and through the winter. The concomitant high-frequency $(2 \mathrm{MHz}) \mathrm{ADCP}$ backscatter time-series nearly mirrored the patterns obtained from the video imagery, and also highlighted a clear inter-annual variability, with higher copepod densities in 2013 relative to 2014. Such inter-annual variability was also evidenced by ground-truth net tow casts from Line P and La Perouse monitoring stations in the vicinity of Barkley Canyon. The low and high-frequency ADCP (75 KHz and $2 \mathrm{MHz}$ ) current data demonstrated an along axis mean flow near the bottom and an up-canyon mean subsurface flow from 70 to $300 \mathrm{~m}$ above the seabed, suggesting a recirculation cell at this segment of the canyon. Based on this circulation pattern and on our video and backscatter data, we propose a conceptual model describing how the topographically-constrained currents along the canyon axis and the up-canyon flow may help trap the seasonally migrating biomass of Neocalaus spp. near the core of its overwintering depth at mid-canyon $(\sim 1000 \mathrm{~m})$. Based on a previously calculated 25 -yr mean of carbon export flux attributed to $N$. plumchrus in the NE Pacific (i.e., $5 \mathrm{~g} \mathrm{C} \mathrm{m}^{2} \mathrm{yr}^{-1}$; min. 1.44, $\max 8.82 \mathrm{C} \mathrm{m}^{2} \mathrm{yr}^{-1}$ - BradfordGrieve et al., 2001), which considers respiration and mortality at the overwintering depth throughout winter after spawning, we estimated that 35-215 tons of carbon reach Barkley Canyon's seafloor yearly over an area of approximately $24 \mathrm{~km}^{2}$. Future studies should aim to further constrain the role of submarine canyons in transporting and concentrating deep zooplankton migrating biomass, as there are at least another 230 submarine canyons in the subarctic NE Pacific, a region where zooplankton biomass is heavily dominated by deep ontogenetically migrating calanoid copepods.
\end{abstract}

\footnotetext{
* Corresponding author at: Ocean Networks Canada, University of Victoria, PO Box 1700 STN CSC, Victoria, BC V8W 2Y2, Canada.

E-mail address: fdeleo@uvic.ca (F.C. De Leo).
} 


\section{Introduction}

Nearly 10,000 submarine canyons exist worldwide predominantly along continental margins, covering a total area of 4.4 million square kilometers, or $1.2 \%$ of the ocean seafloor (Harris et al., 2014a). These abrupt topographic features are key to connecting shallow coastal areas with the deep-sea, channeling and transporting sediments (Oliveira et al., 2007; Puig et al., 2014), organic matter (Vetter and Dayton, 1998, 1999; De Leo et al., 2010, 2014), marine debris (Schlining et al., 2013) and pollutants (Paull et al., 2002). Canyons can focus kinetic energy of internal tides inducing vertical mixing (Zhao et al., 2012; Aslam et al., this volume), and also trigger upwelling through the topographic steering of along-shelf currents (Klinck, 1996; Hickey, 1997; Allen and De Madron, 2009) promoting enhancement of local primary productivity (Sobarzo et al., 2001; Ryan et al., 2005) and the concentration of zooplankton biomass (Greene et al., 1988; MacquartMoulin and Patriti, 1996; Lavoie et al., 2000). Additionally, the topographic focusing of zooplankton and micronekton biomass in submarine canyons may enhance trophic subsidies to larger predatory fish, marine mammals and seabird species (Hooker et al., 1999; Genin, 2004; Moors-Murphy, 2014). Furthermore, due to high-localized productivity in concert with extremely heterogeneous and complex seafloor habitats, high benthic biomass and biodiversity have also been reported for a range of temperate and tropical submarine canyons (Schlacher et al., 2007; McClain and Barry, 2010; De Leo et al., 2010, 2012, 2014; Vetter et al., 2010).

For the Canadian NE Pacific, very little information exists on biological productivity and biodiversity of both pelagic and benthic habitats within submarine canyons, despite the fact that there are at least 40 canyons cutting across the Cascadia Margin north of the Juan de Fuca Strait $\left(48^{\circ} \mathrm{N}\right.$ ) and towards the northern tip of the Haida Gwaii (Queen Charlotte) Islands, at $54^{\circ} \mathrm{N}$ (Harris et al., 2014a, 2014b). Barkley Canyon is perhaps one exception, where several studies have documented high pelagic productivity (Freeland and Denman, 1982) and zooplankton biomass associated with spring-summer upwelling season (Mackas et al., 1997; Allen et al., 2001). Under such conditions, analytical models show that stretching vorticity generated above the canyon topography is strong enough to produce closed cyclonic eddies around $200 \mathrm{~m}$, the depth at which the canyon rim intersects with shelf, causing even strong swimmer macrozooplankton species such as $\mathrm{Eu}$ phausia pacifica and Thysanoessa spinifera to be trapped and transported towards the shore (Allen et al., 2001). However, even though the concentration of zooplankton is relatively well-described for waters above $250 \mathrm{~m}$ in Barkley Canyon, no information exists on the potential for topography-induced transport and aggregation of deep-dwelling ontogenetically migrating zooplankton species. In particular, large calanoid copepod species characteristic of outer shelf waters in the NE Pacific, such as Neocalanus plumchrus, $N$. cristatus and $N$. flemingeri, which are known to undergo strong seasonal ontogenetic vertical migration (Miller et al., 1984; Mackas et al., 1998), have been reported in high densities at the head and near the walls of Barkley Canyon (Allen et al., 2001). Populations of $N$. plumchrus spend late summer through fall as nonfeeding fifth-stage (C5) copepodites in deep waters ranging from 200 to $2000 \mathrm{~m}$, but are mostly concentrated between 400 and $800 \mathrm{~m}$ (Miller et al., 1984; Miller and Clemons, 1988). From late fall to early winter, they molt to the non-feeding adult stage (C6), mate and spawn at or near the overwintering depth, and remain there until they die (Miller et al., 1984). The nonfeeding nauplii then migrate upwards arriving at sea surface as late-stage N6 nauplii or first-stage (C1) copepodites (Miller et al., 1984).

Large-grazing and ontogenetically migrating calanoid copepods are the main components of the total zooplankton biomass in the NE Pacific during spring and early summer (Goldblatt et al., 1999; Mackas and Tsuda, 1999), with $N$. plumchrus comprising up to half of the mesozooplankton biomass in the Alaskan Gyre region (poleward from $45^{\circ} \mathrm{N}$ ). Ontogenetically migrating copepods feed on a variety of food items ranging from diatoms, flagellates, microzooplankton, sinking aggregates, and feces, helping to connect the grazing and microbial food webs (Dagg, 1993; Gifford, 1993; Kobari et al., 2003; Steinberg et al., 2008). Also not surprisingly, large calanoids make up a great proportion of the diets of local salmon populations (Burgner, 1991), myctophids (Kawamura and Fujii, 1988), baleen whales (Kawamura, 1982) and seabirds (Hunt et al., 1993), and can therefore be considered keystone species in the trophodynamics of the NE Pacific pelagic ecosystem (Mackas et al., 1998). Additionally, some studies have shed light on the importance of the mass ontogenetic migration of large grazing calanoid copepods to the downward carbon flux into the mesopelagic zone, often not accounted for by traditional methods for measuring particulate organic carbon (POC) flux (Bradford-Grieve et al., 2001; Kobari et al., 2003, 2008a, 2008b; Steinberg et al., 2008). Furthermore, particularly in Barkley Canyon, recent findings of high concentrations of zooplankton-derived lipid biomarkers in deep-sea sediments at mid canyon depths $(\sim 800-1000 \mathrm{~m})$ suggest the canyon's seafloor is being seasonally enriched by this highly labile organic material, and serving as food for and structuring the benthic communities (Campanyà-Llovet et al., this volume).

The motivation for the present study initiated by unexpected observations of dense aggregations of large calanoid copepods at $970 \mathrm{~m}$ depth in Barkley Canyon, only made possible by the high-definition seafloor video cameras installed and connected through the NEPTUNE cabled observatory (Ocean Networks Canada Data Archive, 2013). Bihourly observations of high densities of these large-bodied copepods ( $\sim 3-8 \mathrm{~mm}$ in prosome length) throughout the entire month of December of 2013, suggested we were observing the nonfeeding C5s and adult C6 stages of either one, or a combination of three Neocalanus species (i.e., N. plumchrus, $N$. cristatus, $N$. flemingeri - identified not only due to the relatively large prosome size, but also to its shape), passively drifting at their overwintering depth. We therefore aimed to test the hypothesis that these observations represented peak densities reached after the onset of overwintering migration by Neocalanus spp., and further to evaluate the seasonal and interannual variability in this downward ontogenetic migration. Additionally, we addressed the potential role of Barkley Canyon's topography in concentrating this migrant biomass. We analyzed a $\sim 20$-month time-series of bi-hourly video imagery combined with high-frequency acoustic Doppler current profiler (ADCP) data sampled at $0.1 \mathrm{~Hz}$ resolution from Barkley Canyon's node of Ocean Networks Canada's (ONC) NEPTUNE seafloor cabled observatory. To the best of our knowledge, the high temporal resolution of these observations is unprecedented for studies dealing with the seasonal dynamics of ontogenetically migrating zooplankton. The longest and most consistent sampling of the temporal and vertical distribution of Neocalanus spp. in offshore waters of Vancouver Island (NE Pacific) comes from the Line $\mathrm{P}$ and La Perouse bank long-term monitoring stations (Mackas et al., 2001). However, both programs rely on limited net-tow sampling at frequencies ranging from twice to three times per year (Mackas, 1992). In addition to our three main objectives, the present study aimed to further characterize the importance of ontogenetically migrating zooplankton species as sources of POC reaching Barkley Canyon's seafloor and promoting a strong pelagic-benthic coupling. 


\section{Materials and methods}

\subsection{Study area}

Barkley Canyon is a highly sinuous shelf-incising submarine canyon located $\sim 100 \mathrm{~km}$ offshore Vancouver Island in the NE Pacific (Fig. 1A and B). It possesses multiple head branches intersecting the continental shelf edge, all discharging in the main canyon axis around mid-slope depths of 400-600 m (Fig. 1B). Storm and along-shelf current-induced sediment resuspension events over the shelf generate strong bottom and intermediate nepheloid layer flows, which transport and redistribute sediments and organic matter in the upper slope in the vicinities of the canyon head (Baker and Hickey, 1986). Barkley Canyon harbors a mosaic of benthic habitats and biological communities, as it combines methane seeps with hydrate outcrops, patches of deep-water corals and flat sedimented seafloor, all bathed in hypoxic waters within upper and lower boundaries of the NE Pacific oxygen minimum zone (Chatzievangelou et al., 2016; De Leo et al., 2017; Seabrook et al., 2017; Domke et al., 2018).

The physical circulation dynamics at Barkley Canyon's head and shallower flanks (surface down to $450 \mathrm{~m}$ ) has been relatively well constrained in a coupled observational and modelling study (Allen
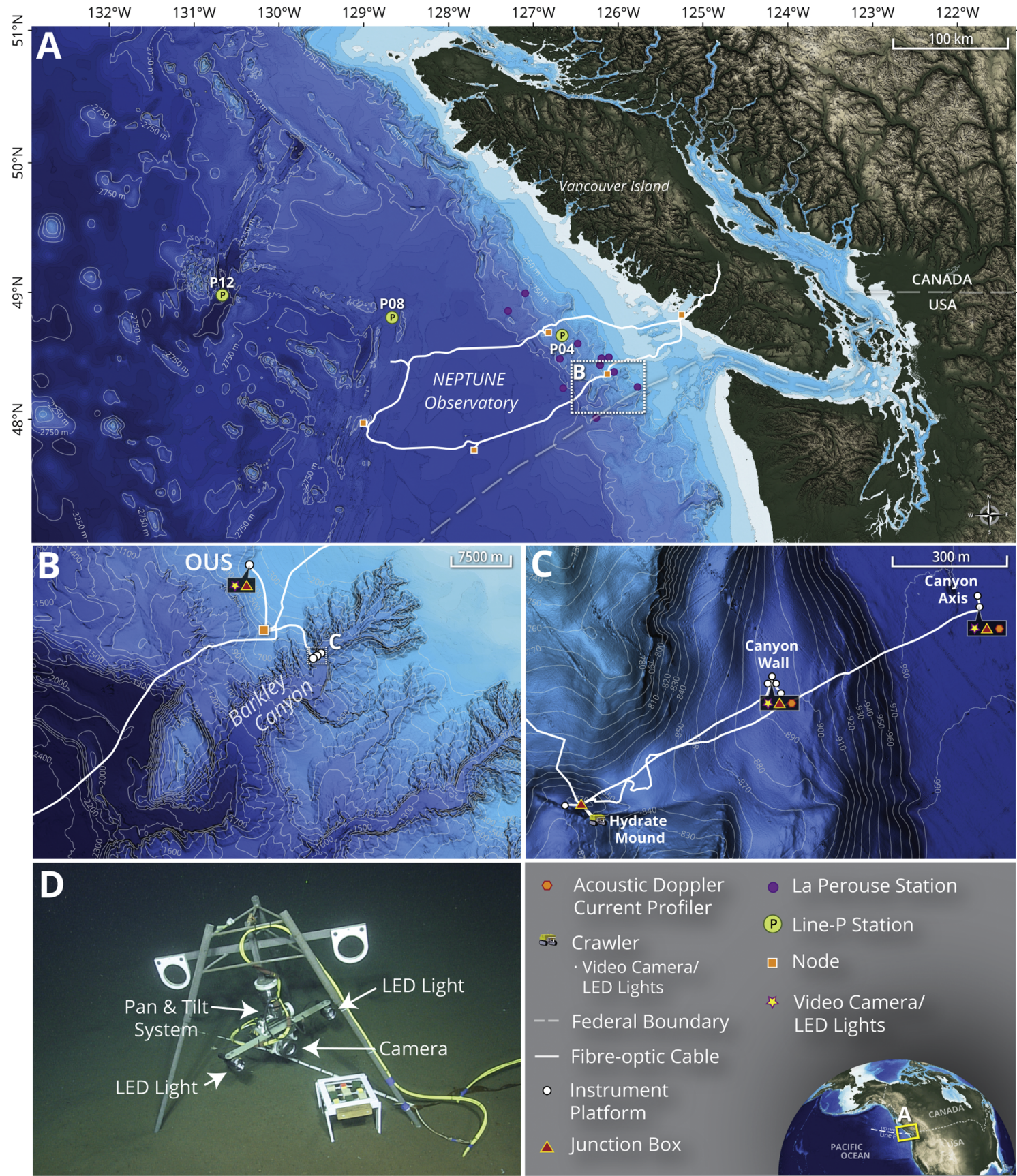

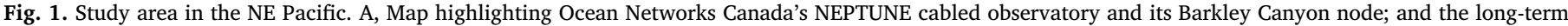

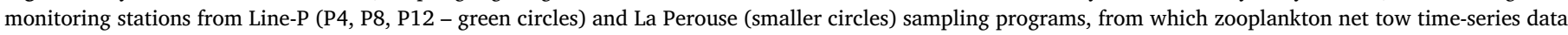

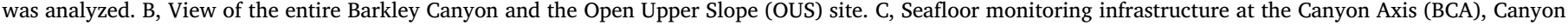

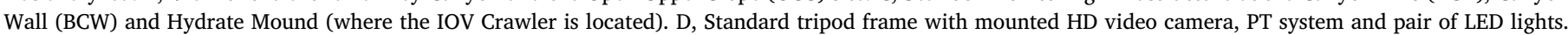

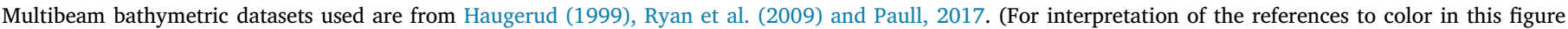
legend, the reader is referred to the web version of this article.) 
et al., 2001). The flow structure at Barkley Canyon's upper section from the upper slope towards the shelf edge has four main characteristics during an upwelling regime: (1) the near surface NW wind-driven along-shore flow passes over the canyon unaltered; (2) the flow near the bottom (above the bottom boundary layer) at the shelf-break is advected over and drops into the canyon. Stretching generates cyclonic vorticity turning the flow up canyon, which crosses the downstream canyon rim generating anticyclonic vorticity; (3) flow over the upper slope is advected into the canyon and upwelled onto the shelf; (4) the deeper slope flow $(\sim 400 \mathrm{~m})$ enters the canyon at the downstream rim turning cyclonically (entire flow structure described in Allen et al (2001)).

\subsection{Biological and environmental data overview and analysis}

In the present study, we used data from multiple oceanographic instrumentation installed in Barkley Canyon and adjacent slope from ONC's NEPTUNE seafloor cabled observatory (Fig. 1A-C). The NEPTUNE observatory, since its initial installation in 2009/2010, has collected close to 8 years of oceanographic data in Barkley Canyon and at 4 other active node locations in the NE Pacific (Fig. 1A) (Barnes et al., 2010). For the purpose of the present study we analyzed observatory time-series data from May 23, 2013 to Jan 12, 2015 ( $~ 599$ days). We used video imagery from fixed seafloor cameras installed in three different locations and depths: Barkley Canyon Axis (BCA) at $970 \mathrm{~m}$ and
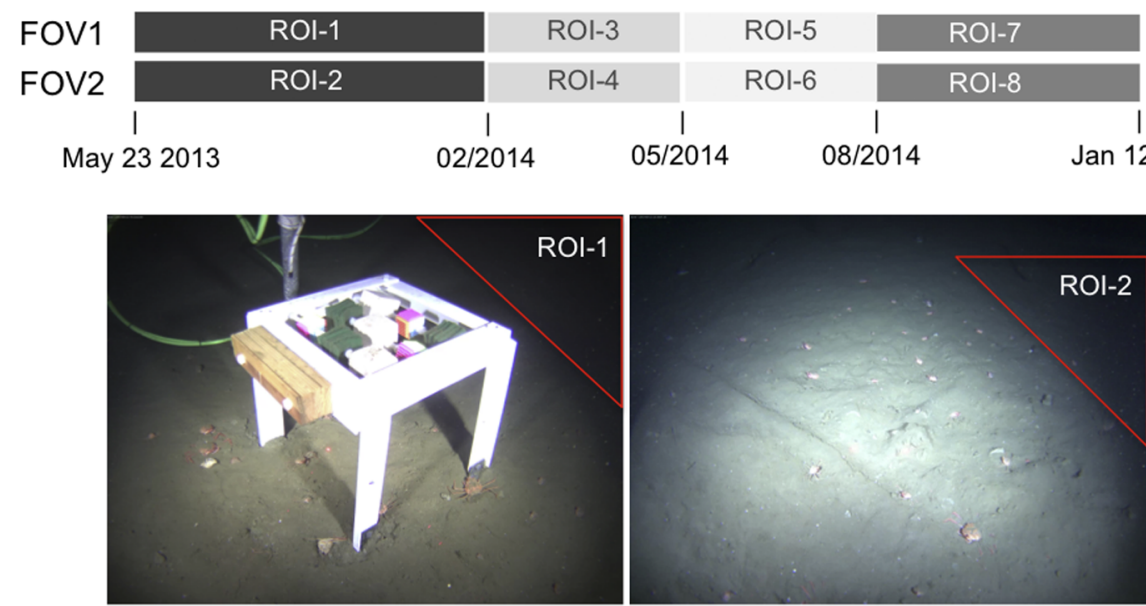

A
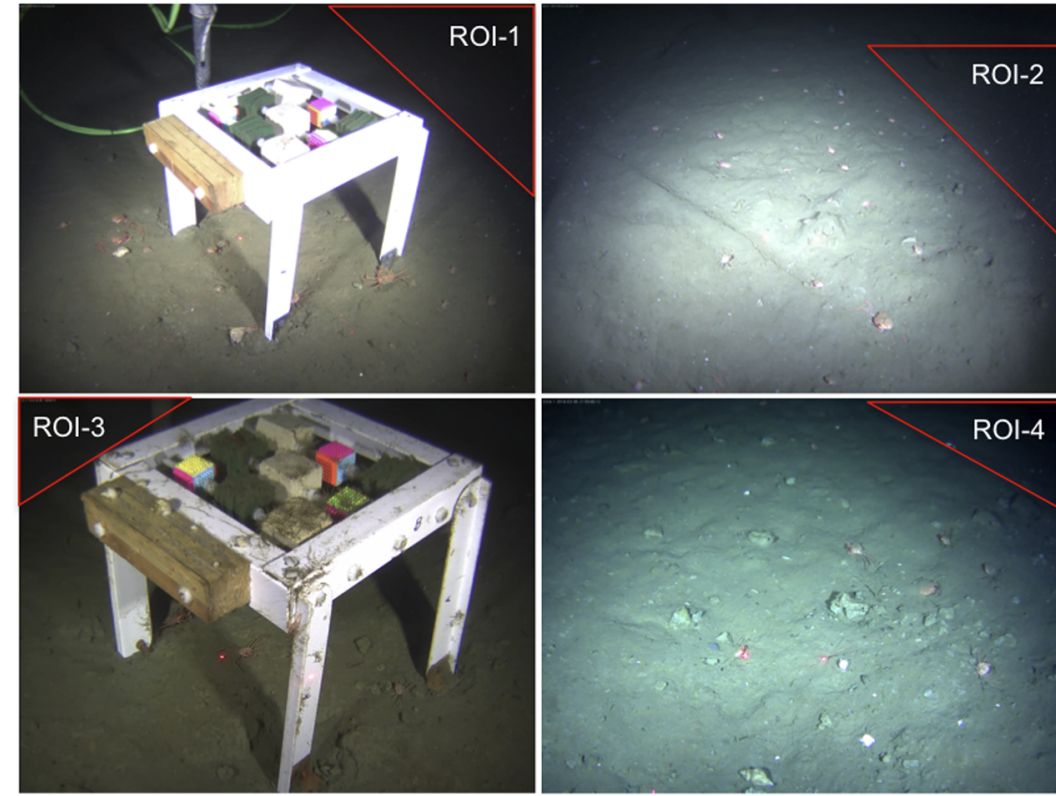

B
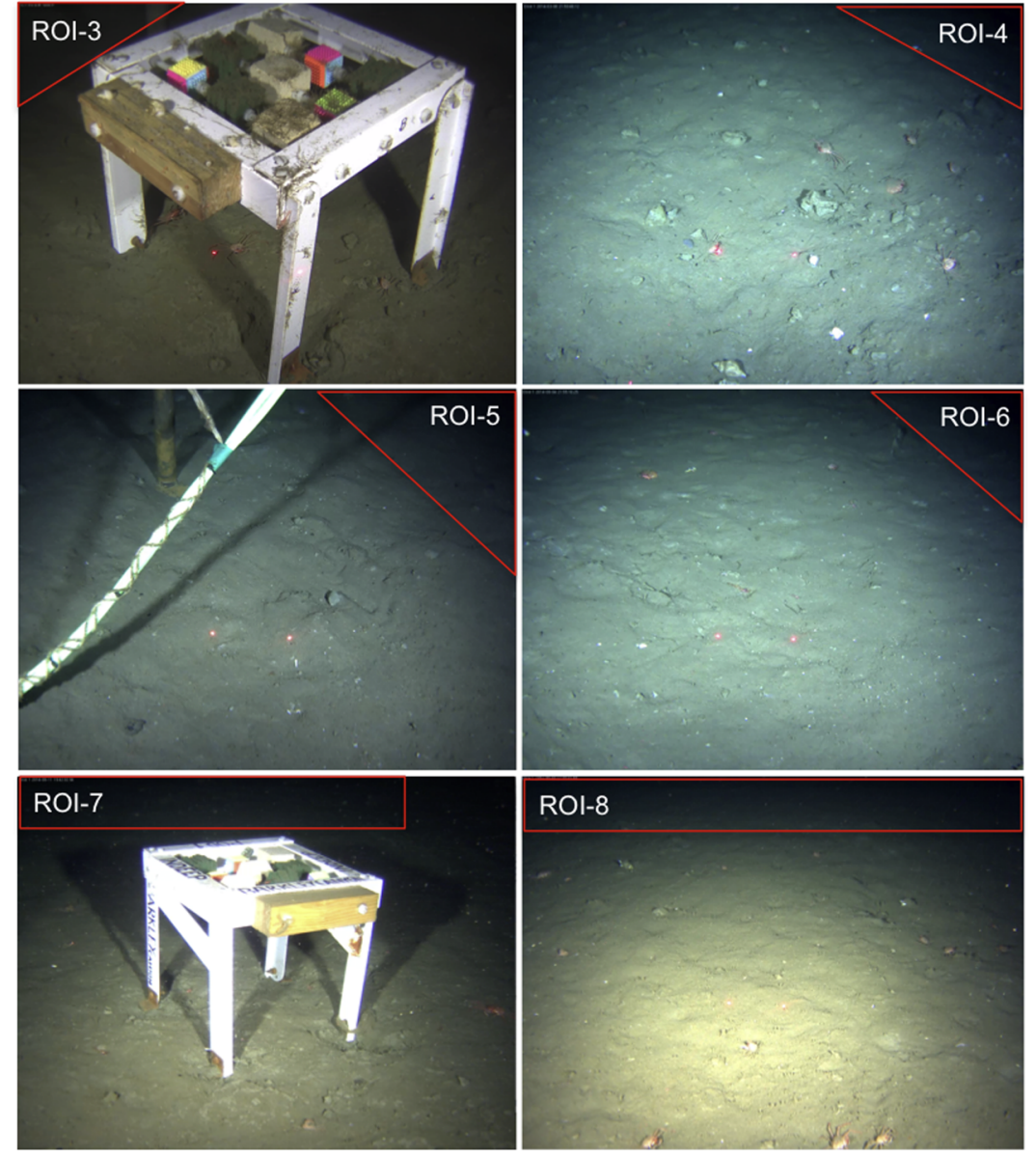

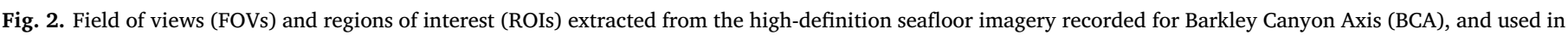

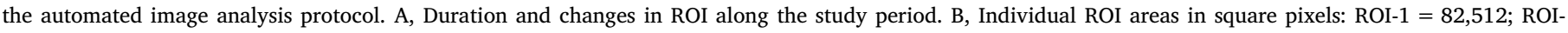
$2=53,592$, ROI-3 $=207,040$, ROI- $4=297,600$, ROI- $5=202,884$, ROI- $6=120,012$, ROI-7 $=71,868$, ROI- $8=70,500$. 
Canyon Wall (BCW) at $870 \mathrm{~m}$ (Fig. 1C), and on the Open Upper Slope (OUS) at $400 \mathrm{~m}$ (Fig. 1B), in order to assess the presence and estimate the densities of C5 and adult stages of overwintering copepods (likely a combination of three species within the genus Neocalanus) near the seafloor (i.e., during overwintering at depth). We also used qualitative data from a video camera installed in a mobile Internet Operated Vehicle (IOV) located at a methane hydrate outcrop, approximately $600 \mathrm{~m}$ SW from the BCW site (Fig. 1C). Prior to May 2013 the seafloor video cameras installed in Barkley Canyon did not have enough image resolution, or a systematic recording schedule, preventing us from using the entire time series dating back to 2010 .

The fixed seafloor cameras installed in BCA, BCW and OUS routinely record 5-minute videos at two-hour intervals, triggered by turning on a pair of Remote Ocean Systems (ROS) LED lights (100 W, > $406 \mathrm{~lm}$ ). This automated recording schedule is intended to limit the exposure of deep-sea benthic and demersal organisms to artificial lighting, in an attempt to reduce disturbance potentially altering faunal behavior (Robert and Juniper, 2012). All seafloor cameras installed and redeployed after May 2013 are either one of two models: an AXIS PT185 or a SubC Imaging Dragonfish, both with high-definition (1080 horizontal lines of resolution) imaging sensors. All cameras are attached to a ROS-485 Pan and Tilt (PT) unit and mounted in a stainless-steel tripod frame with $2 \mathrm{~m}$ between each leg at the base, and $1.8 \mathrm{~m}$ in total height (Fig. 1E). The final camera height above the seabed is normally $\sim 65 \mathrm{~cm}$, after accounting for the PT unit mounted above, and for $2-3 \mathrm{~cm}$ of sinking of the tripod frame into the soft-muddy seafloor. Therefore, at a static position with a Tilt angle of $45^{\circ}$ the camera images roughly $6 \mathrm{~m}^{2}$ of the seafloor considering its lense aperture angles. A pair of ROS lasers with beams $10 \mathrm{~cm}$ apart is mounted aligned with the camera's horizontal plane, providing scaling of the seafloor.

In addition to our observations from the video imagery, and to evaluate Barkley Canyon's bottom current dynamics potentially affecting the transport of ontogenetically migrating copepods, we used a low-frequency upward-looking $75 \mathrm{KHz}$ acoustic Doppler current profiler (ADCP) located in BCA. The device was configured with vertically stacked measurement cells each $8 \mathrm{~m}$ in thickness, with the centre of the
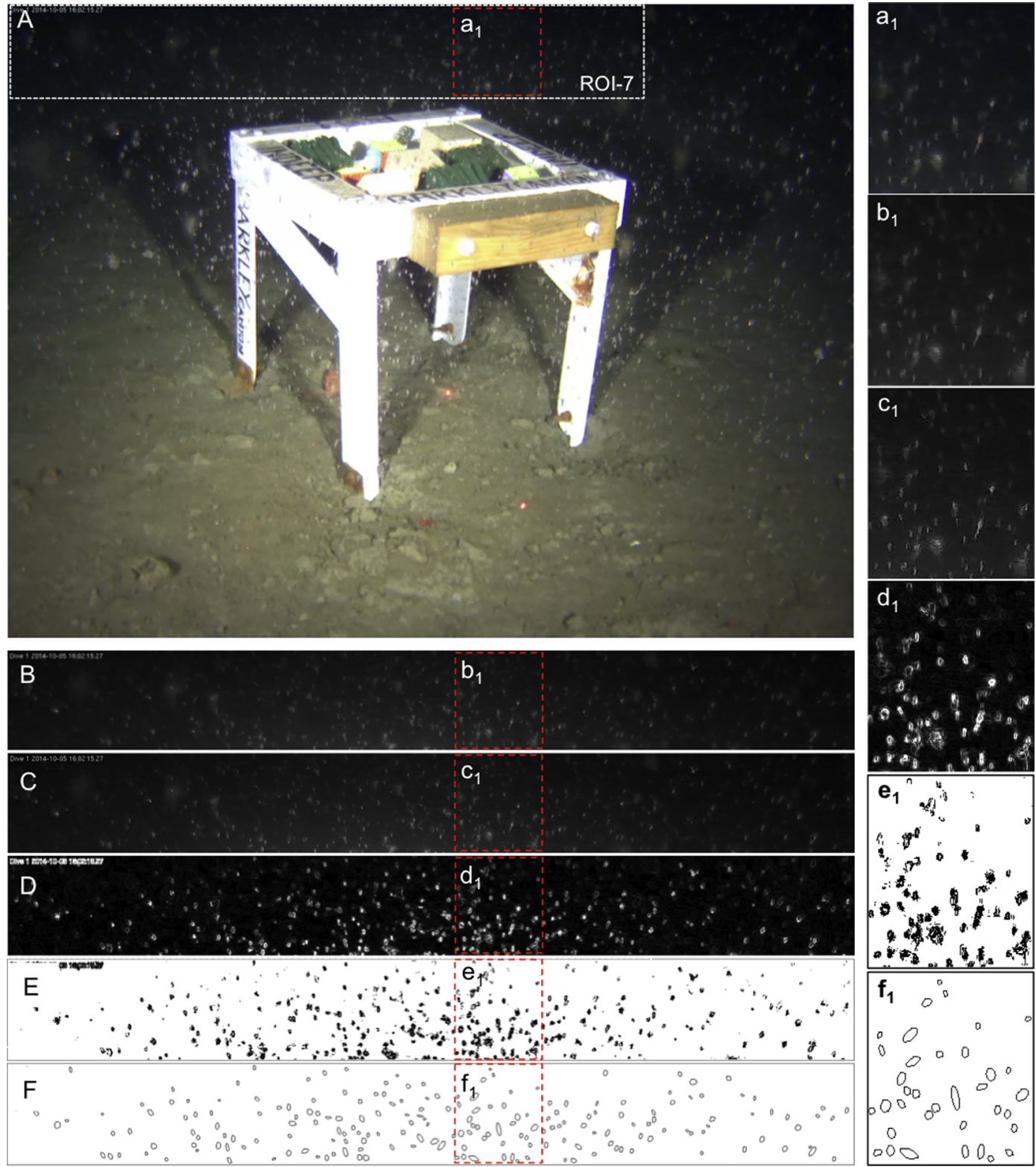

Fig. 3. Summary of steps performed by the automated image analysis protocol. A, original image (using ROI-7 as example). B, 8-bit grayscale image transform. C, Sharpening. D, Edge delimitation. E, Thresholding. F, Output of 'analyze and count particles' function on ImageJ. Detail inset images are enlarged in the right-side panels. 
first valid cell located at $18 \mathrm{~m}$ above the seafloor. These settings allowed current velocity and direction estimates up to about $600 \mathrm{~m}$ above the canyon seafloor. A co-located high-frequency upward-looking $2 \mathrm{MHz}$ ADCP was used to estimate the near bottom currents using 102 vertically stacked measurement cells, each of $1.43 \mathrm{~cm}$ in thickness. With this configuration, near bottom currents could be measured between 0.2 and $1.5 \mathrm{~m}$ above the seabed. Additionally, the $2 \mathrm{MHz}$ ADCP from BCA and BCW were also used to evaluate the backscatter reflectivity strength, also within a $1.5 \mathrm{~m}$ range above the seabed, as an additional proxy for the presence of the ontogenetically migrating copepods (Fig. 1C). NEPTUNE observatory ADCP's are set to record data at their highest sampling rates $(0.1 \mathrm{~Hz}$ and $0.5 \mathrm{~Hz}$ for the high and low frequency ADCPs, respectively), however, current and backscatter data were averaged to 1-h intervals, a high-enough resolution to resolve tidal oscillations and to nearly match the bi-hourly video observations.

\subsection{Overwintering copepod density estimates from video imagery}

We selected two concomitant camera fields of view (FOV) from two distinct Pan positions, as the cameras are originally set to monitor the seafloor aiming at two or more different headings, one of which, pointing at a benthic larval colonization experiment (INDEEP frame) (Fig. 2; 1D). The selection of at least two FOVs from the same sampling period was used to investigate possible effects of variable lighting and scattering conditions as well as to optimize the contrast between the bright foreground (i.e., white copepods) and the dark background (i.e., non-illuminated water column), as the camera is originally intended to image the seafloor at an oblique angle (i.e., not looking directly to the water column). From each FOV a different optimal foreground/background contrast area (herein referred as region of interest, ROI) was cropped from the original video prior to proceeding with the copepod counting routine described below (Fig. 2). Additionally, throughout the 20-month long time-series, the camera FOVs changed slightly in May 5 of 2014, right after the yearly maintenance and redeployment using a remotely operated vehicle. Therefore, we had to use an adaptive sampling strategy choosing the best ROIs to account for those changes (Fig. 2).

A Python script was developed to automatically extract 10 still frame grabs from each 5-min video segment (5 frames per FOV) recorded from May 23, 2013 to Jan 12, 2015. A total of 1,674 video segments from the BCA camera, 33,486 still frame grab images were generated. A minor gap in the data occurred during the above-mentioned maintenance of the observatory infrastructure, from May 5-9 of 2014 (Fig. 2A). While the same script was also used to extract still frames from the videos from the BCW and OUS' video cameras, a preliminary assessment revealed that deep migrating copepods were virtually absent from the shallower OUS site; and the still images extracted from the BCW camera were corrupted prior to the automated analysis routine. Therefore, we only used the original videos from both these sites in a qualitative analysis.

The next step consisted of a computer-automated image analysis protocol implemented using a macro function in the software ImageJ (Rasband, 1999). The macro pre-registered the following automated post-processing steps that were applied to all 33,486 images: (1) the cropping of the target ROIs specific to each FOV along the time-series; (2) image 'binarization', from color to grayscale (8-bit transform); (3) 'sharpening', and enhancing edge delimitation for individual copepods; (4) 'thresholding', generating a binary image from the bi-chromatic grayscale image, and finally; (5) 'analyze and count particles', fitting an ellipsoid function to any particle in a predefined diameter range and circularity matching both size spectra and shape, respectively, of C5stage and adult Neocalanus spp. After several trial runs to perfect this step, we selected a particle size range between 18 and $144 \mathrm{sp}$ (squarepixel), and circularity between 0.1 and 1.0 (dimensionless number, 1 being a perfect circle, and determined using the formula: $c=4 \pi \times a$ / $p^{2}$, where: $\mathrm{c}=$ circularly, $\mathrm{a}=$ area, $p^{2}=$ perimeter square), which provided the best results in properly identifying copepods in the images (all these steps are summarized in Fig. 3).

The particle counting protocol worked under the assumption that the vast majority of particles detected and counted in the predefined size and shape ranges were copepods. While this assumption may initially seem unrealistic, a thorough manual examination of video segments throughout the entire time series revealed that only a very small number of non-identified mysids and small pelagic shrimps were also distinguishable from the video, but still larger than the defined copepod size range. Large organic aggregates derived from sporadic sediment resuspension events or from sinking of marine snow, and large discarded appendicularian houses (likely from Bathochordaeus spp.), only scarcely present during the observation period, were always too large to be detected by the image analysis protocol. Small discarded appendicularian houses, in a size rage similar to the copepods (Tomita et al., 1999), could potentially have added some bias in the automated countings, however, a qualitative inspection of the video imagery throughout the study period revealed this group was virtually absent at those depths in Barkley Canyon. Also, sediment particles were not in the size-range identifiable by the automated counting protocol. Furthermore, when large objects such as drifting jellyfish (mostly Poralia rufescens, Tiburonia granrojo and Periphylla sp.), and sablefish (Anoplopoma fimbria) were captured in the predefined ROIs after being automatically extracted from the original videos, these images were excluded from the analysis.

The automated copepod counting protocol allowed for the analysis of 35 images per minute, i.e., a total computational time of $16 \mathrm{~h}$ to analyze the 33,500 still images. On the other hand, manual counts from image subsets (performed for statistical comparisons and efficiency testing of the automated counts - see next section) required an average of five minutes per image, and therefore an equivalent of 1 year of manual visual counts would be required in order to analyze the entire dataset (assuming an 8-h work day).

\subsection{Statistical analyses}

In order to test for the accuracy of the automated image analysis protocol, we compared the output of copepod density estimations by the ImageJ macro with densities obtained by the manual visual counts (i.e., with the unaided human eye) performed by a single trained individual. We randomly selected 50 images from the 8 different ROIs along the time-series (i.e., 400 images in total) and performed linear regression analysis using the Pearson's correlation coefficient. Once again, when non-target objects such as jellyfish, sablefish or large organic aggregates were present in randomly selected images, those were discarded from the comparative image set.

One-way analysis of variance (ANOVA) of both copepod density counts (obtained from imagery data in BCA) and mean backscatter strength data (from $2 \mathrm{MHz}$ ADCPs in BCA and BCW) were performed to verify significant differences between seasons and years. Post-hoc Tukey tests were carried out to identify significant between-group (i.e, seasons or years) variability. A pairwise linear correlation analysis using the Pearson's linear correlation coefficient was run between the imagery count data and the mean backscatter strength data (only for $\mathrm{BCA}$ ), in order to verify the correspondence between the two methods in estimating densities of ontogenetically migrant copepods. Those two analyses were chosen after all datasets passed standard normality tests.

\subsection{Ground-truthing zooplankton data}

Complementary to our seafloor video and acoustic Doppler data from the cabled observatory, we analyzed 5 years (2011-2015) of zooplankton net data from the long-term Line $\mathrm{P}$ (http://www. waterproperties.ca/linep/) and La Perouse Bank monitoring programs (Fig. 1A; Mackas, 1992). Sampling along Line P takes place in February, late May-early June, and late August-early September. La Perouse 
stations are sampled either immediately before or after the summer and fall Line P cruises. Here we consider stations sampled south of $49^{\circ} \mathrm{N}$, east of $128.5^{\circ} \mathrm{W}$ and west of the shelf (i.e. over the shelf break and offshore; Fig. 1A). Zooplankton were collected with vertical net hauls of $56 \mathrm{~cm}$ mouth diameter Bongo nets $(236 \mathrm{~mm}$ mesh). 'Shallow' casts ( $\mathrm{n}=108$ ) were hauled to the surface from $250 \mathrm{~m}$ or $10 \mathrm{~m}$ above the bottom for stations with $<250 \mathrm{~m}$ bottom depth. 'Deep' casts $(\mathrm{n}=21)$ were hauled to the surface from a depths of $1200 \mathrm{~m}$ offshore (note that deep net hauls for February were only collected in 2015). The zooplankton net tow time-series data were used to determine seasonal, inter-annual, and coarse (i.e. below and above $250 \mathrm{~m}$ ) vertical abundance patterns of all combined Calanoid species, as well as of individual species, including $N$. plumchrus, $N$. cristatus, N. flemingeri, Calanus marshallae and Eucalanus bungii, near our Barkley Canyon study area, and within the timeframe of the observatory time-series data.

\section{Results}

\subsection{Barkley canyon current dynamics}

Barkley Canyon exerts significant influence on the dynamics of the near bottom oceanic currents at our study site, BCA. These currents are aligned with the orientation of the local segment of the canyon thalweg (North-South) with the low-frequency non-tidal component directed downslope towards the south (Fig. 4A; also refer to map in Fig. 1C). This location is significantly removed from the canyon walls ( $>300 \mathrm{~m}$ ) and other topography such that we expect it to be representative of flow along the thalweg and not a result of tidal rectification. Although we lack observations from further up and down the canyon axis, we have no reason to believe that the flow is non-continuous. The southerly mean current that underlies the progressive vector diagram (PVD,
(A)

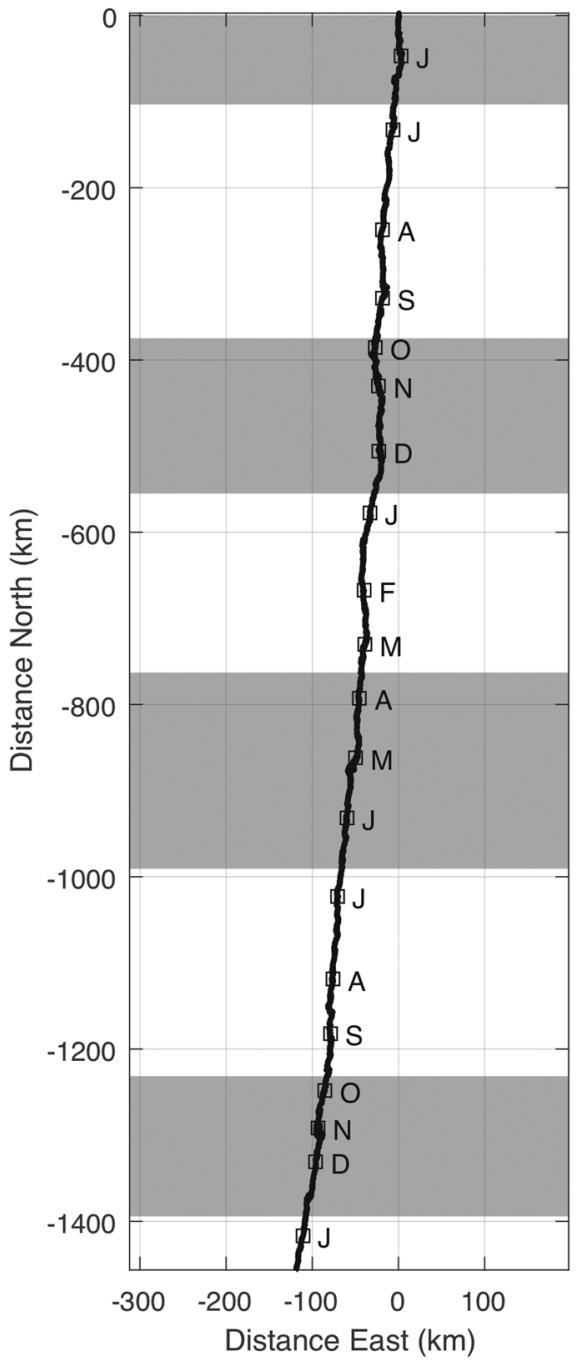

(B)

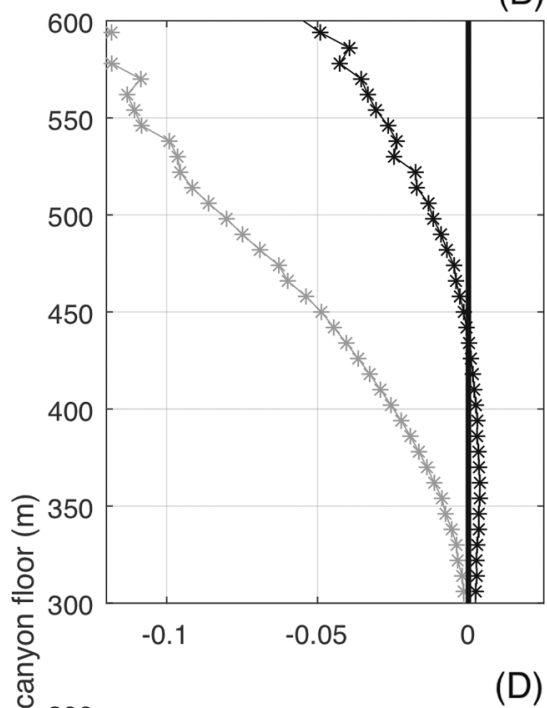

(D)

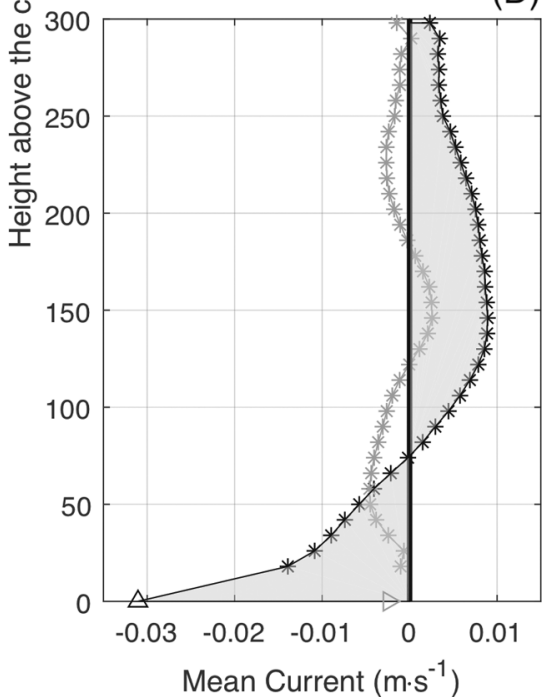

(C)

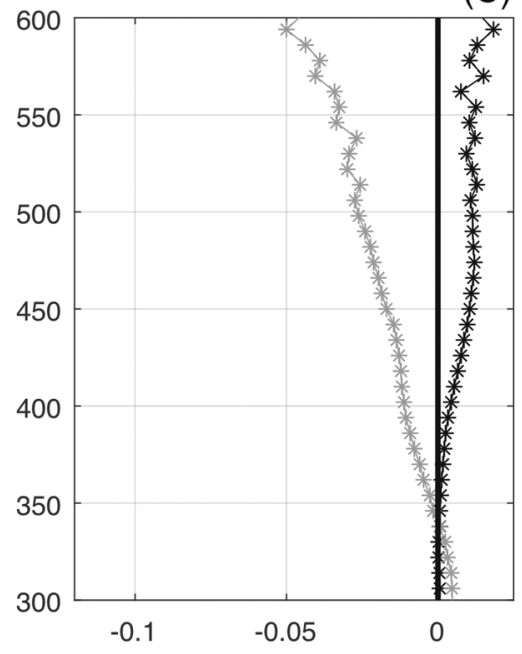

(E)

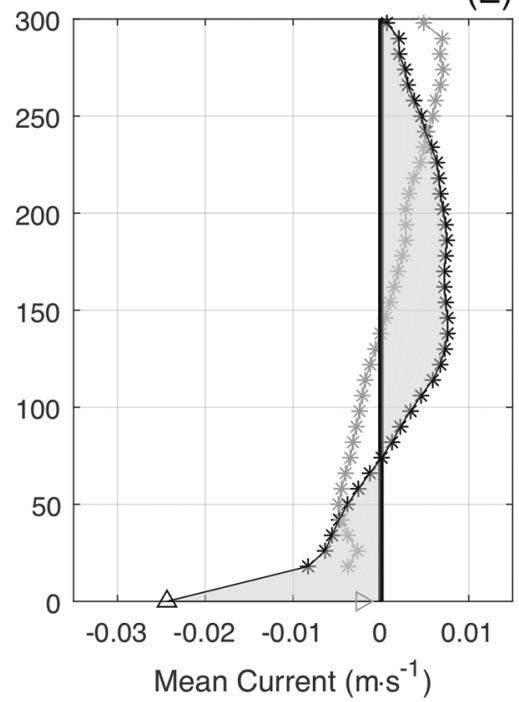

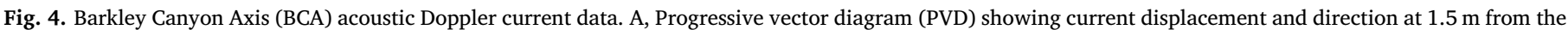

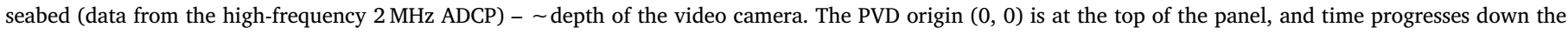

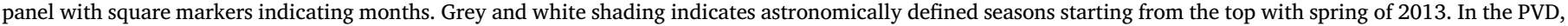

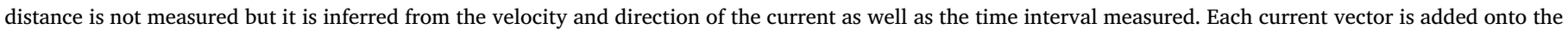

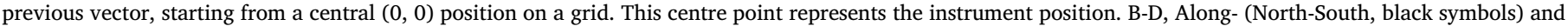

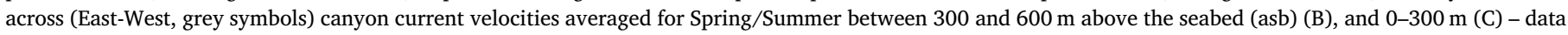

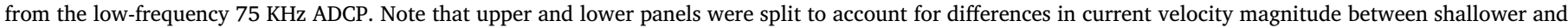

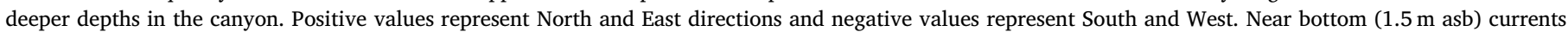

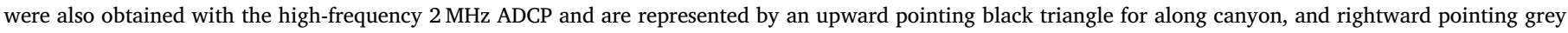
triangle for across canyon flow. C-E, same as described for panels B-D, but for averaged Fall/Winter currents. 
Fig. 4A) has a mean value of $2.77 \mathrm{~cm} \mathrm{~s}^{-1}$ at $182^{\circ} \mathrm{T}$ over the duration of the 20 -month study period. As interpreted by small changes in spacing between the monthly cumulative flow depicted in the PVD, the seafloor monthly mean current velocities did not vary significantly in time (Fig. 4A). The average current over the combined spring and summer is $3.10 \mathrm{~cm} \mathrm{~s}^{-1}$ and the combined autumn and fall season is $2.44 \mathrm{~cm} \mathrm{~s}^{-1}$ (Fig. 4D and E), both persistently downslope (south).

Examining the vertical structure of the currents at BCA, the circulation in the bottom half profile of the water column (up to $300 \mathrm{~m}$ above the seabed) is influenced by Barkley Canyon's topography. The crossaxis flows are generally of lower intensity with respect to along-axis flows, which are particularly intensified within $18 \mathrm{~m}$ near the bottom (Fig. 4D and E). In both summer/spring and autumn/winter, at about $70 \mathrm{~m}$ above the seafloor the axial current reverses to up canyon until $300 \mathrm{~m}$ above seafloor (Fig. 4D and E); and in a one-dimensional sense delineates a closed circulation pattern, i.e., a downslope flow along the bottom being replaced with an upper return flow. Right above the upper limit of this circulation cell, $300 \mathrm{~m}$ above the seafloor, the currents intensify and become cross-axis to the canyon (Fig. 4B and C). This is the depth of the adjacent continental slope, and the currents are more aligned with the larger scale local oceanic circulation. Our study location is at the northern end of an eastern boundary current system, the California Current System. The California Current is a wind-driven surface current directed equatorward with a poleward flowing countercurrent beneath, the California Undercurrent (CUC) (see e.g. Thomson and Krassovski, 2010). In Fig. 4, panels B and C, the strengthening westward flow away from the seafloor is likely due to the influence of the California Undercurrent.

\subsection{Estimated copepod densities near the seafloor}

The linear regression analysis revealed that the copepod density estimates using the automated image analysis protocol were in strong agreement with the manual visual counts (Fig. 5). All ROI linear regressions were highly statistically significant ( $\mathrm{p}$-values, Pearson $\mathrm{R}^{2}$ correlation coefficients, slope and intercept values are provided in Fig. 5). These results therefore provided us with confidence for interpreting the data from the entire time-series, and highlighted the importance of a high-throughput image analysis protocol for handling such large amount of video imagery, recorded at very high temporal resolution.

Copepod density estimates using the automated image analysis procedure provided somewhat variable between-year and strong seasonal temporal patterns (Fig. 6). Overall densities ranged from 0 to $1.5 \times 10^{-3}$ cop. $\mathrm{sp}^{-1}$ (copepods per square pixel) throughout the entire observation period, with values steadily increasing starting in midfall ( October) both in 2013 and 2014, and peaking throughout winter months (November through January). Statistically significant differences were observed between seasons $(F=712.8 ; p<0.0001)$, with higher densities during fall $\left(\mathrm{m}=4.6 \times 10^{-4}\right.$, sd $\left.=1.8 \times 10^{-4}\right)$ and winter $\left(\mathrm{m}=3.3 \times 10^{-4}\right.$, sd $\left.=2.1 \times 10^{-4}\right)$, and lower densities in spring $\left(\mathrm{m}=1.7 \times 10^{-4}, \mathrm{sd}=1.4 \times 10^{-4}\right)$ and summer $\left(\mathrm{m}=2.9 \times 10^{-4}\right.$, $\mathrm{sd}=1.7 \times 10^{-4}$ ). Copepod densities steadily decreased immediately after 2013/14 winter months, reaching minimum values during spring and summer of 2014. Unfortunately, we lost connectivity to the seafloor instrumentation in Barkley Canyon on January 12, 2015, and a secondyear density minimum could not be observed. In addition to the marked seasonal variability in copepod densities, there were also significantly higher densities in spring $\left(\mathrm{m}=3.4 \times 10^{-4}\right.$, sd $\left.=1.5 \times 10^{-4}\right)$ and summer $\left(\mathrm{m}=3.9 \times 10^{--4}\right.$, sd $\left.=1.5 \times 10^{-4}\right)$ of 2013 compared to the same periods in 2014 (spring: $\mathrm{m}=1.2 \times 10^{-4}$, $\mathrm{sd}=0.9 \times 10^{-4}$, summer: $1.7 \times 10^{-4}$, sd $=1 \times 10^{-4}$ ).

A qualitative visual inspection of a large subset of videos from the OUS video camera revealed that deep migrant copepods were completely absent from this shallower site (at $400 \mathrm{~m}$ ) outside of Barkley Canyon. Also from qualitative video analysis from the fixed video camera at BCW, and from the camera installed in the mobile IOV crawler platform at the Hydrates' site, both located in a plateau near the northern canyon flank, similar seasonal patterns in copepod densities as in BCA were observed (i.e., the downward migration signal was evident between Oct-Jan in both years), however, with considerably lower densities in the canyon flank (Supplementary Videos 1-4).

A preliminary analysis of the high-frequency $2 \mathrm{MHz}$ ADCP backscatter data from the BCA and BCW sites revealed a sustained 'contamination' of the backscatter signal with strong spikes occurring at 2-h intervals (Fig. 7A and D). A careful examination of the data along with the video imagery from both locations revealed the contamination was due to frenzied swimming behavior by sablefish (Anoplopoma fimbria), a species known to be attracted by the artificial lights (Widder et al., 2005). Since the video camera, which records video every two hours, and the ADCP are located only a few meters apart, this sediment resuspension signal triggered by sablefish is routinely captured by the ADCPs. Thus, data from the 30 min periods following the turning on of
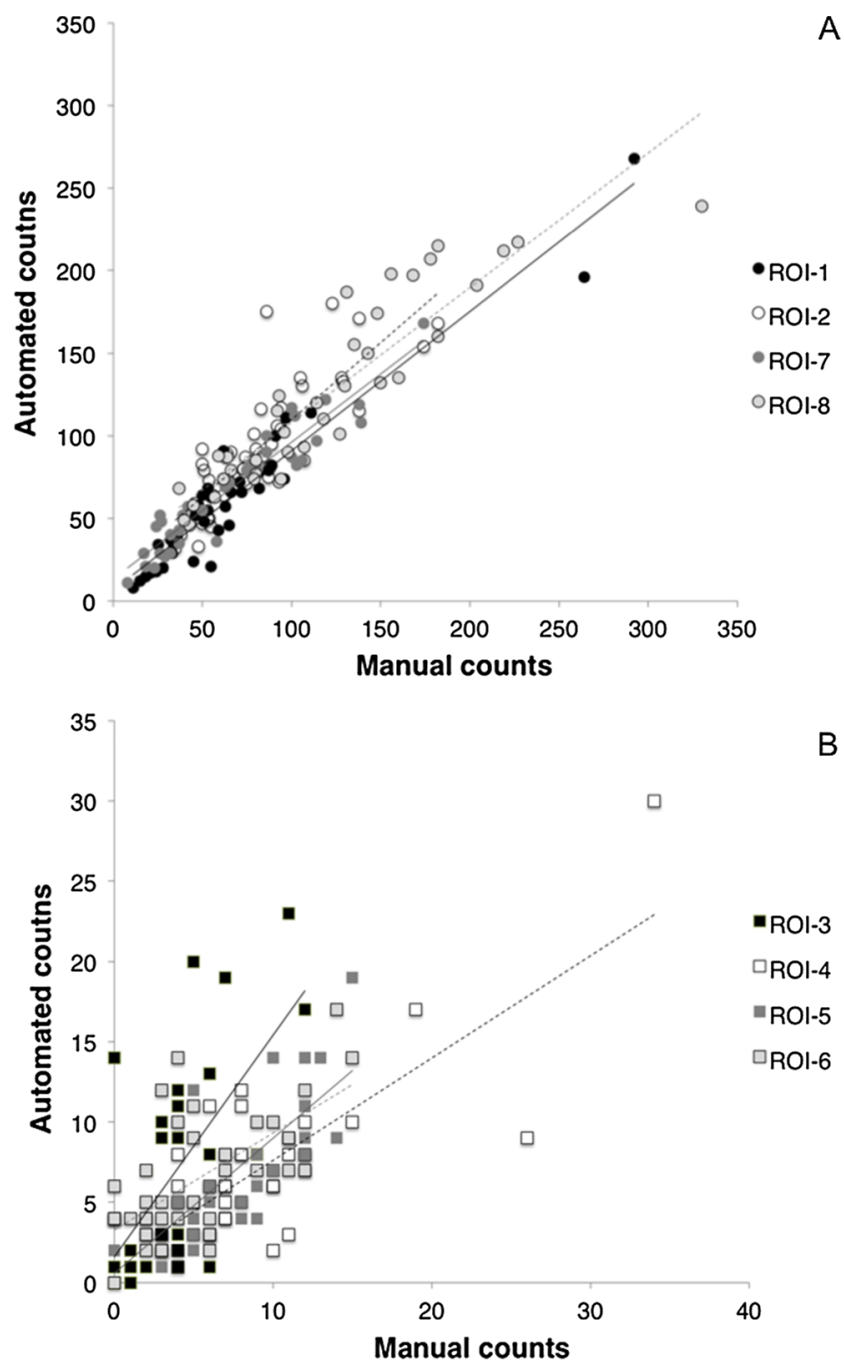

Fig. 5. Scatter plots of manual vs automated copepod counts for all ROIs of BCA's video camera. Linear regression analysis parameters (slope, intercept, Pearson's $\mathrm{R}^{2}$ coefficient, $\mathrm{N}$ ) for all regressions are: ROI- $1, \mathrm{y}=0.843 \mathrm{x}+6.6298$, $\mathrm{R}^{2}=0.92, \mathrm{n}=38$; ROI- $2, \mathrm{y}=0.9335 \mathrm{x}+16.322, \mathrm{R}^{2}=0.69286, \mathrm{n}=44$; ROI$3, \mathrm{y}=1.38 \mathrm{x}+1.6089, \mathrm{R}^{2}=0.40, \mathrm{n}=40 ;$ ROI-4, $\mathrm{y}=0.6369 \mathrm{x}+1.2468$. $\mathrm{R}^{2}=0.61, \mathrm{n}=39 ; \mathrm{ROI}-5, \mathrm{y}=0.8412 \mathrm{x}+0.5 .889 ; \mathrm{R}^{2}=0.59, \mathrm{n}=36$; ROI-6, $\mathrm{y}=0.6036 \mathrm{x}+3.2834, \quad \mathrm{R}^{2}=0.41, \quad \mathrm{n}=41 ; \quad \mathrm{ROI}-7, \quad \mathrm{y}=0.826 \mathrm{x}+13.487$, $\mathrm{R}^{2}=0.89, \mathrm{n}=35$, ROI-8, $\mathrm{y}=0.8164 \mathrm{x}+26.397, \mathrm{R}^{2}=0.82, \mathrm{n}=38$. All ROI linear regressions are highly statistically significant $(\mathrm{p}<0.00001)$, and respective regression lines on graph match data symbology (i.e, ROI with filled symbols $=$ solid lines, with empty symbols $=$ dash lines). 


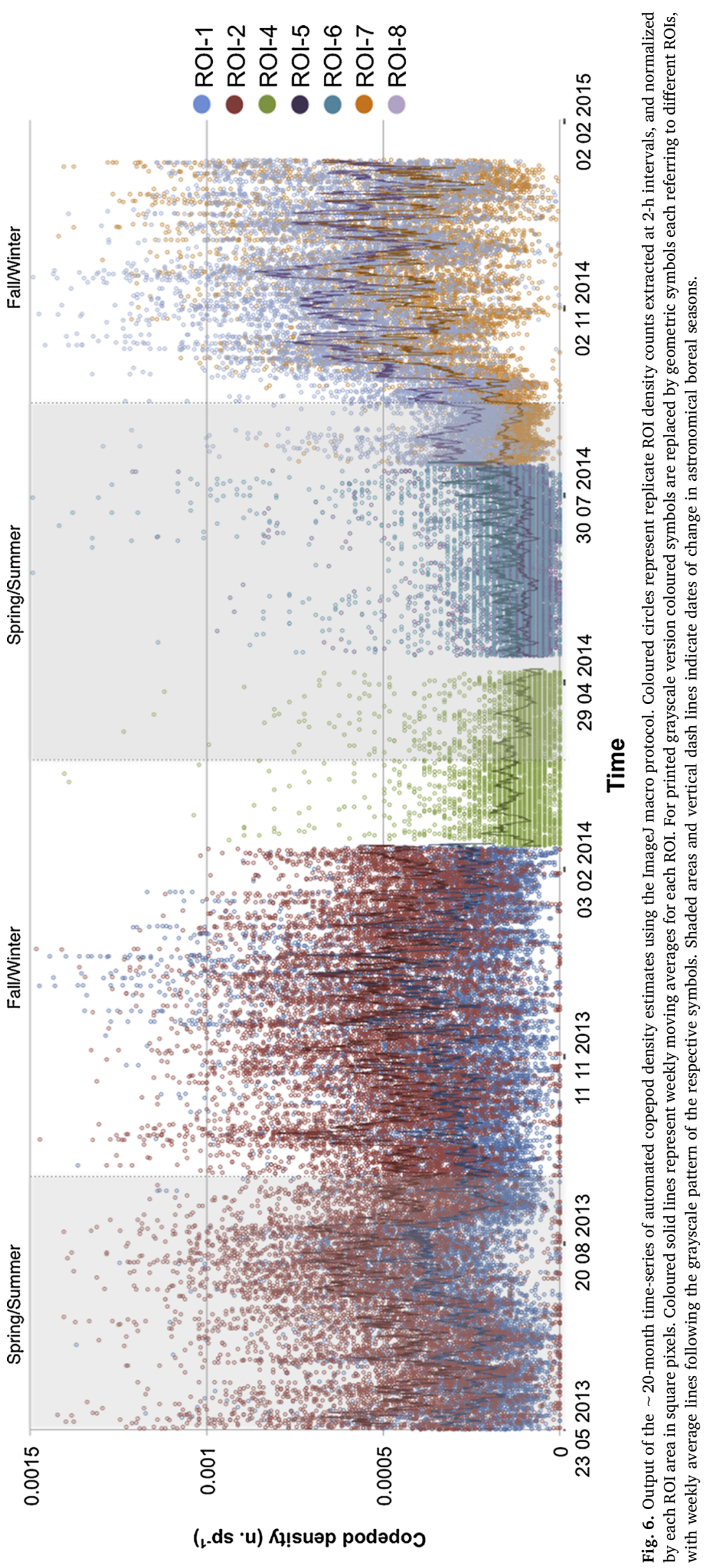



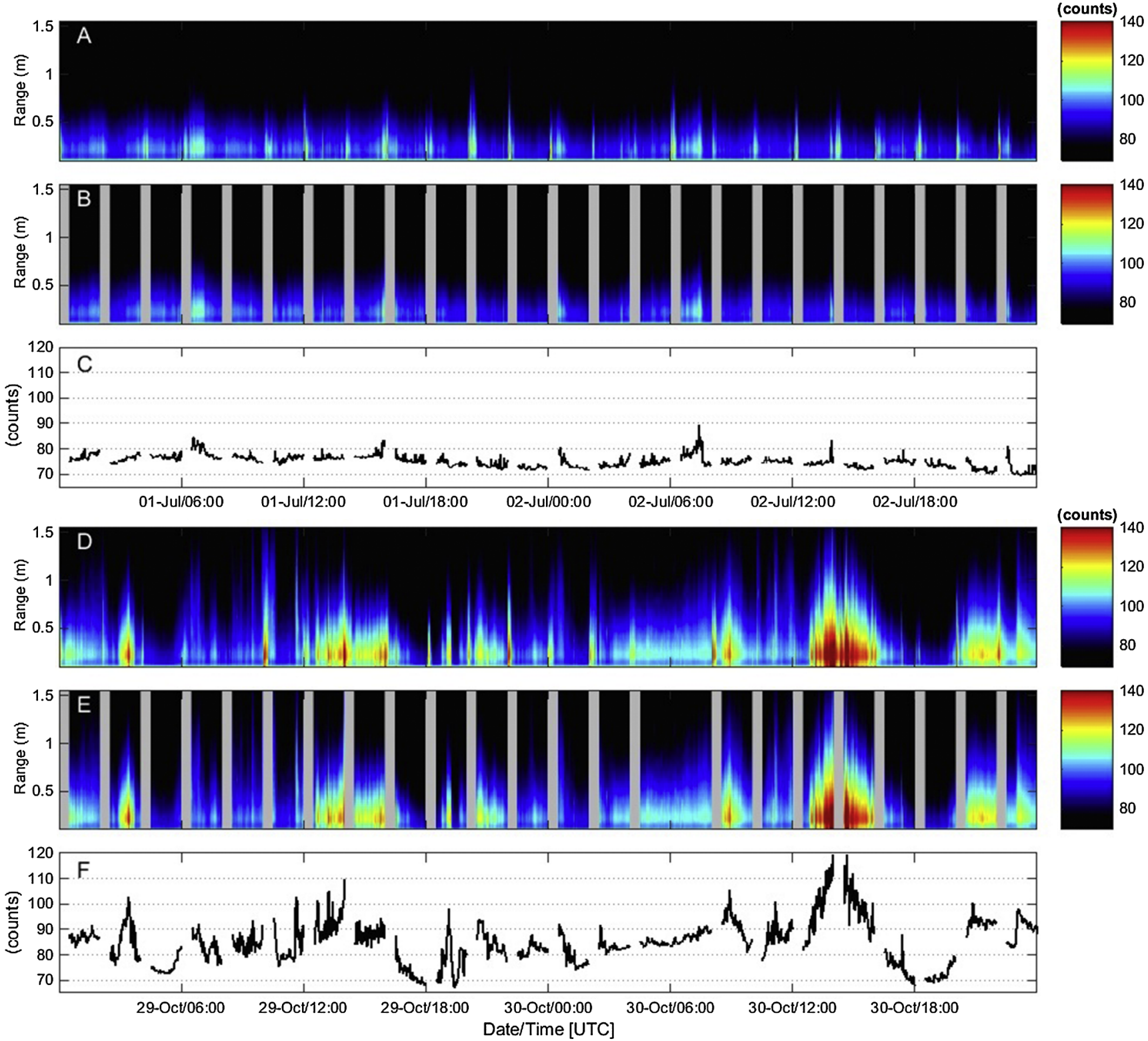

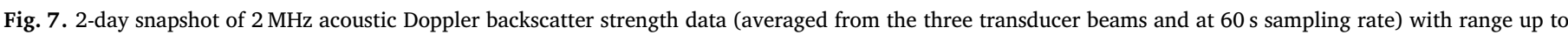

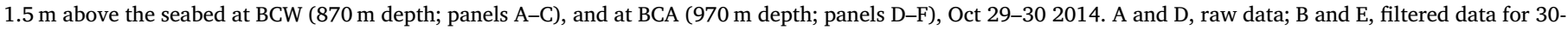

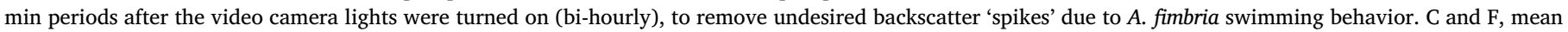
backscatter signal a highest sampling resolution (60 sec).

the video cameras were removed from the analysis (Fig. 7B and E), which was sufficient to allow the measured backscatter to return to a baseline level prior to the light activation. After removal of the backscatter spikes and analysing the entire $\sim 20$-month time-series, the overall seasonal and inter-annual patterns of the acoustic Doppler backscatter data at BCA nearly mirrored the copepod densities near the seafloor obtained from the video imagery (Fig. 8A and B - compare with Fig. 6), with a strong statistically significant positive linear correlation between the two variables $(r=0.48$; $d f=6600 ; p<0.0001)$. Particularly noticeable was the matching for the two fall/winter density peaks between Oct-Jan of both 2013/14 2014/2015, coinciding with Neocalanus C5 and adults overwintering at depth (Fig. 8A and B). Differences in backscatter strength data were statistically significant between seasons for the two studied years combined $(\mathrm{F}=0.558 .1$, $\mathrm{p}<0.0001)$, with higher values during fall $(\mathrm{m}=85.94$, $\mathrm{sd}=6.5)$ and winter $(\mathrm{m}=83.46$, $\mathrm{sd}=6.0)$, and lower values during spring $(\mathrm{m}=79.81, \mathrm{sd}=4.0)$ and summer $(\mathrm{m}=79.97, \mathrm{sd}=4.9)$. Spring and summer provided the only non-significant between-season comparison (adjusted $\mathrm{p}=0.84$ ). Additionally, significant between-year differences were observed $(\mathrm{F}=158.4, \mathrm{p}<000.1)$, with higher mean backscatter strength in $2013(\mathrm{~m}=84.16, \mathrm{sd}=5.3)$ than in $2014(\mathrm{~m}=81.53$, $\mathrm{sd}=6.8$ ).

The backscatter strength data for the entire 20-month time-series at BCW, located at $870 \mathrm{~m}$ and near the northern canyon flank, did not show the same strong seasonal patterns as observed in the canyon axis (BCA) site (Fig. 8C and D). However, the backscatter strength was still significantly higher during fall $(\mathrm{m}=70.6, \mathrm{sd}=5.3)$ and winter $(\mathrm{m}=70.1$, sd $=3.2)$ of both studied years $(\mathrm{F}=90.7, \mathrm{p}<0.0001)$ compared with spring $(\mathrm{m}=69.51, \quad \mathrm{sd}=3.29)$ and summer ( $\mathrm{m}=68.51$, $\mathrm{sd}=3.83$ ), also indicating the presence of migrant copepods. Unfortunately we do not have comparable quantitative data on copepod densities from the video imagery at BCW, but qualitative analysis of a large number of videos clearly showed a much less intense deep water presence at the canyon flank, which is about $100 \mathrm{~m}$ 

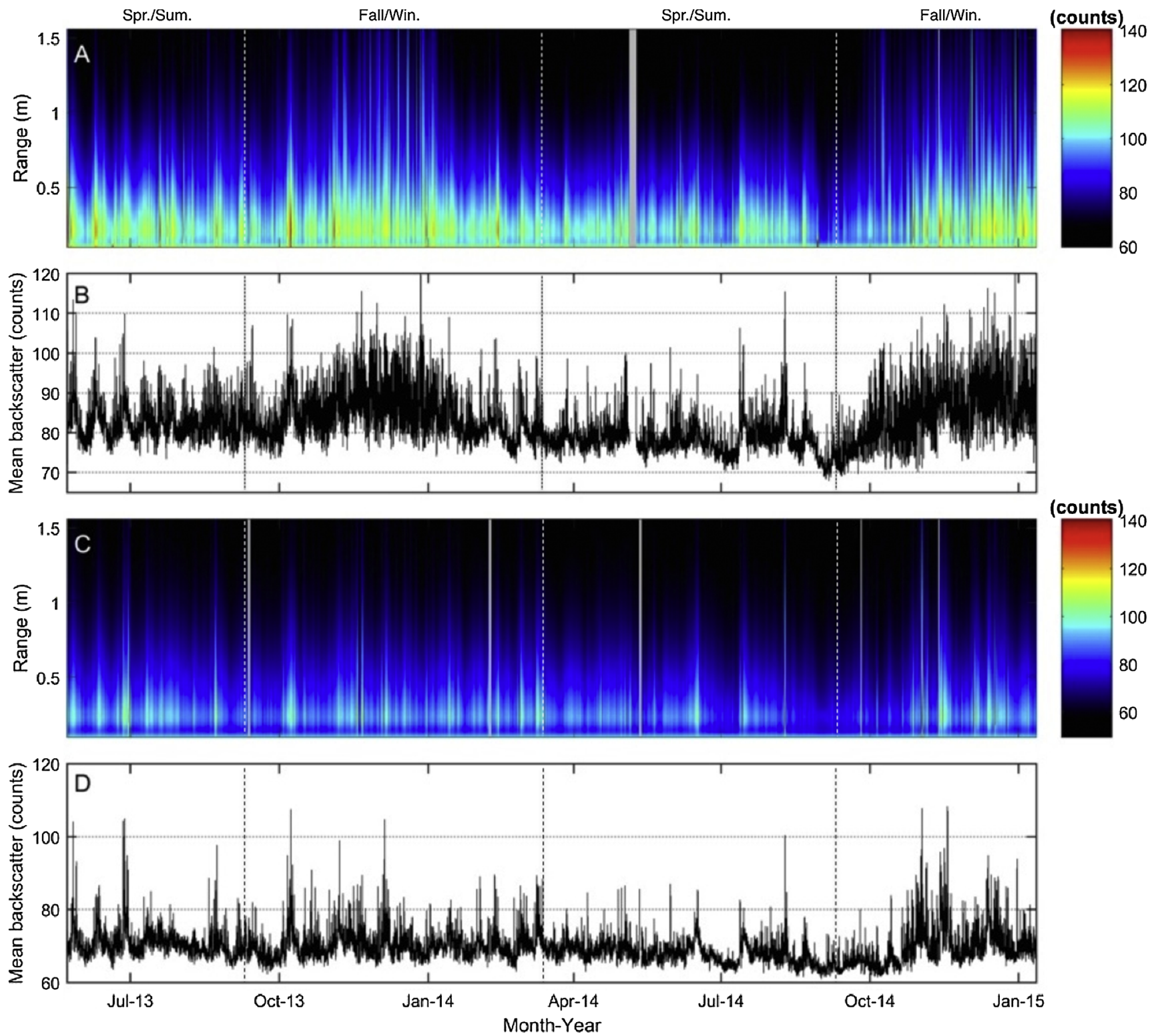

Fig. 8. 20-month time-series of $2 \mathrm{MHz}$ acoustic Doppler backscatter strength data (averaged from three transducer beams) with range up to $1.5 \mathrm{~m}$ above the seabed at BCA ( $970 \mathrm{~m}$ depth, panels A and B) and BCW ( $870 \mathrm{~m}$ depth, panels C and D). A,C, raw data binned into 2-h averages. B and D, mean backscatter signal averaged from the three transducer beams and at $60 \mathrm{~s}$ sampling rate. Vertical dashed lines indicate dates of change in astronomical boreal seasons.

shallower and about $1 \mathrm{~km}$ to the northwest from BCA (Supplementary Videos 1 and 2).

\subsection{5-yr time-series of net-tow zooplankton data}

The zooplankton net cast data obtained from Line $\mathrm{P}$ and off-the-shelf La Perouse monitoring stations show a close correspondence to our near seafloor observations determining the seasonal timing of the downward vertical migration of Calanoid copepods. Furthermore, it also provided us with confidence in ascertaining that the copepods we were seeing in the video imagery as well as that were captured by the Doppler backscatter signal, belonged to the three species within the genus Neocalanus (i.e., $N$. plumchrus, $N$. cristatus, and $N$. flemingeri). From the deep net cats data we conclude that both $N$. plumchrus and $N$. cristatus dominate video and acoustic signals as they occur at much higher abundances in the area (Fig. 9). The abundance of $N$. flemingeri is relatively low, which is expected given this species' more oceanic distribution. Calanus marshallae is largely absent from the deep late-season samples, and $\mathrm{Eu}$ calanus bungii abundance is also relatively low (Fig. 9). Additionally, the animals present at our video camera sites were characterized by a more robust body-form than E. bungii, which can be discriminated both on video and frame grab still images on the basis of greater body length to width ratios, greater transparency, and a clearly defined circular lipid sac.

Now considering Neocalanus spp. (but likely mostly $N$. pluchrus and $N$. cristatus) as our target taxa, the abundance of juvenile stages (C1-C4) was similar in both shallow and deep casts across months and with the 5 -year pooled samples (Fig. 10, upper panels), suggesting that most juvenile individuals were resident in the upper water column, and therefore agreeing with expectations for this stage of Neocalanus spp. developmental cycle, i.e, undergoing rapid somatic growth while feeding on phytoplankton near the surface. In contrast, the abundance of C5 stages shifted from surface dominance in May and June to deep waters by late August-September, indicating the onset of the downward migration (Fig. 10, mid panels). The abundance of adult (C6) animals began to increase at depth in the late summer and were sampled at depth as late as February (Fig. 10, lower panels), again reflecting a close correspondence between our video and acoustic Doppler time-series 

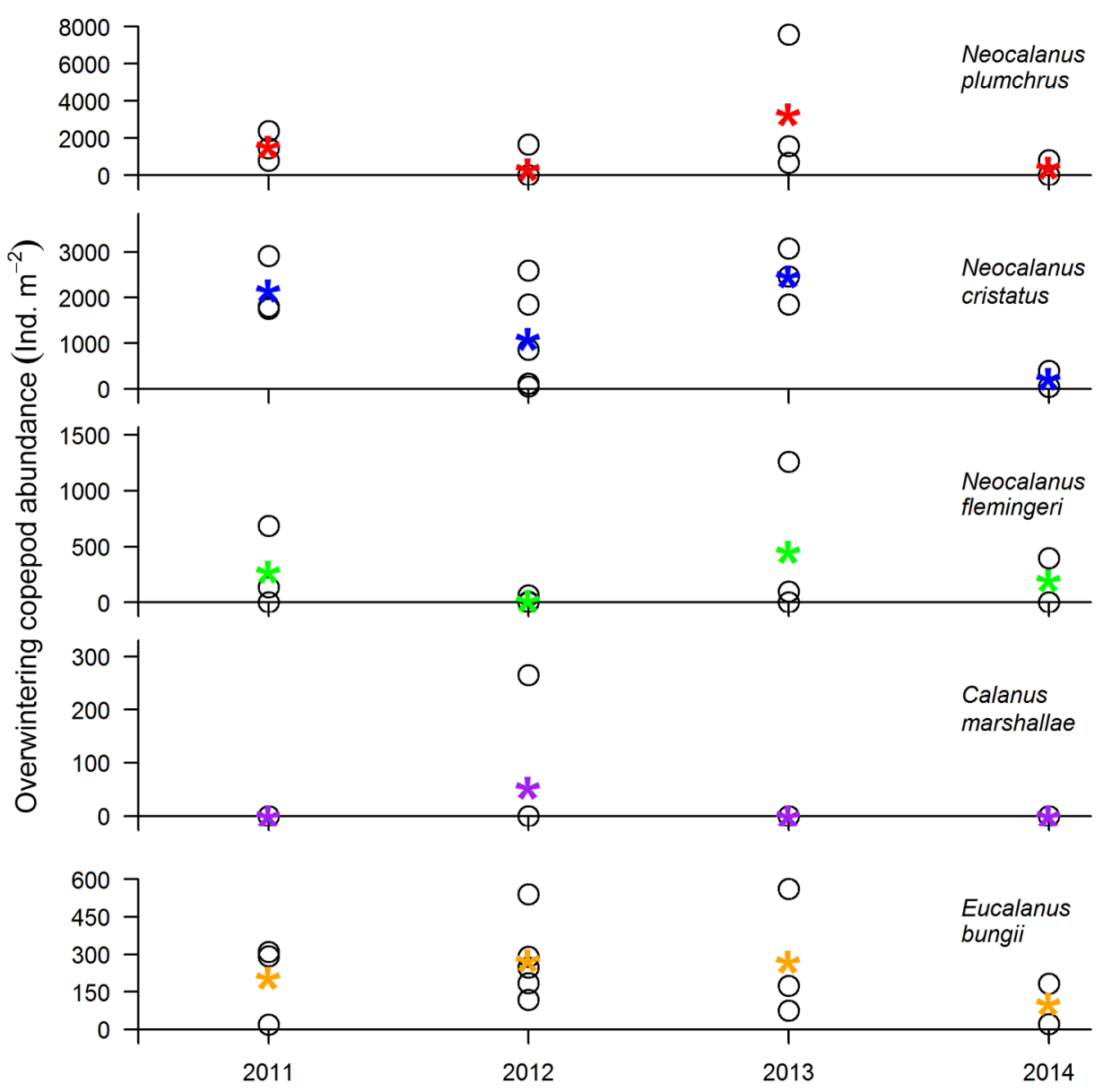

Fig. 9. Interannual (2011-2014) pattern of abundance (individuals $\mathrm{m}^{-2}$ ) for large-bodied Calanoid copepods sampled with deep (1200-0 m) vertical Bongo net casts $(n=21)$ during late-August and September Line P and La Perouse cruises. Open symbols represent species/stage abundance values for each net cast during each year. Mean annual abundance values are identified by coloured star symbols. Neocalanus spp. (panels 1-3 from the top; red, blue, green) are represented by overwintering copepodite stages C5 and C6; Calanus marshallae (panel 4; purple) are represented by overwintering stage C5; and Eucalanus bungii (panel 5; orange) are represented by copepodite stages C3-C6. Note that $E$. bungii is characterized by a 2-year life history pattern with multiple overwintering stages (C3-C6) some which will and will not overwinter in any given year. Thus, we may have overestimated overwintering $E$. bungii in any given year if "non-overwintering" stages C3-C6 were still present in the surface. (For interpretation of the references to color in this figure legend, the reader is referred to the web version of this article.) observations spanning from May 2013 to January 2015.

The Line P and La Perouse net cast zooplankton dataset also displayed a noticeable inter-annual variability in the abundance of late stage Neocalanus spp. in the deep (>1000 m) net casts (Fig. 11). The abundance of pre-migratory animals in shallow casts was greater in 2013 relative to 2014, similar in pattern to overwintering animal abundance in 2013 and 2014 (right panel), suggesting that the low overwintering abundance at depth in 2014 was due to poor surface success during the spring /summer of 2014.

\section{Discussion}

\subsection{Temporal variability of Neocalanus spp. ontogenetic migration}

Our study reports on an unprecedented high-resolution data timeseries witnessing the seasonal timing and between year variability of the ontogenetic vertical migration of Neocalanus spp., a key mesozooplankton genus in the trophic dynamics, ecosystem function and carbon export into the mesopelagic zone of the subarctic NE Pacific (Mackas, 1992; Mackas et al., 1998, 2001; Bradford-Grieve et al., 2001). The use of the NEPTUNE seafloor cabled observatory offered a novel and insightful avenue for efficiently monitoring this large-scale zooplankton deep overwintering migration, which is highly coupled with and driven by surface climate variability (Mackas et al., 1998, 2001). Previously, the seasonal and interannual variability in Neocalanus spp. overwintering migration was based solely on coarse discrete sampling using vertical net casts (Mackas et al., 1998, 2001).

Our results were in close agreement with the known ontogenetic migration cycle described for Neocalanus spp. (Miller et al., 1984), i.e., C5 copepodite stages vertically migrating down to depths of 800-2000 m mostly throughout fall and winter, molting into mature adults prior to spawning; and nauplii ascending to surface waters to feed, and further $\mathrm{C} 1-\mathrm{C} 4$ copepodite stages remaining at surface feeding on phytoplankton during spring and summer upwelling conditions (life cycle summarized in Fig. 1 of Mackas et al., 1998). Furthermore, the nearly perfect match between the video imagery and the high-frequency acoustic Doppler backscatter strength data at BCA site (Figs. 6 and 8 , respectively) suggest we were able to capture the exact timing of the mass arrival of the downward migrant Neocalanus individuals at their overwintering depth (mid to late October for both studied years). From the previously described life history for this genus (Miller et al., 1984; Miller and Clemons, 1988) Neocalanus C5s start leaving the surface waters in late summer (or slightly earlier during years of warm upper ocean temperatures), which would appear inconsistent with our observations of a deep abundance peak occurring only in mid-October. However, since the observed abundance peak timing was similar in both 2013 and 2014, it suggests that the timing of peak abundance at our Barkley Canyon study site (1000 m depth) is less related to surface development. Possible reasons for this discrepancy could be: (1) a vertically staggered descent (1-2 months in duration) to the ultimate overwintering depth (recording that true overwintering depth range spans down to $2000 \mathrm{~m}$ - Mackas et al., 1988); or (2) animals at our BCA camera site (not descending from surface waters above the canyon) are being transported (at depth) to the Barkley Canyon's observatory site at approximately the same time each year.

The time-series of high-resolution imagery displaying the downward overwintering migration of Neocalanus spp. in Barkley Canyon, which is arguably an unexpected and novel visual observation (e.g., Supplementary Video 5), now enhances our ability to monitor the timing and intensity of the annual seasonal ontogenetic migration of Neocalanus spp. with respect to interannual surface ocean climate variability. The observed differences in Neocalanus spp. densities at 


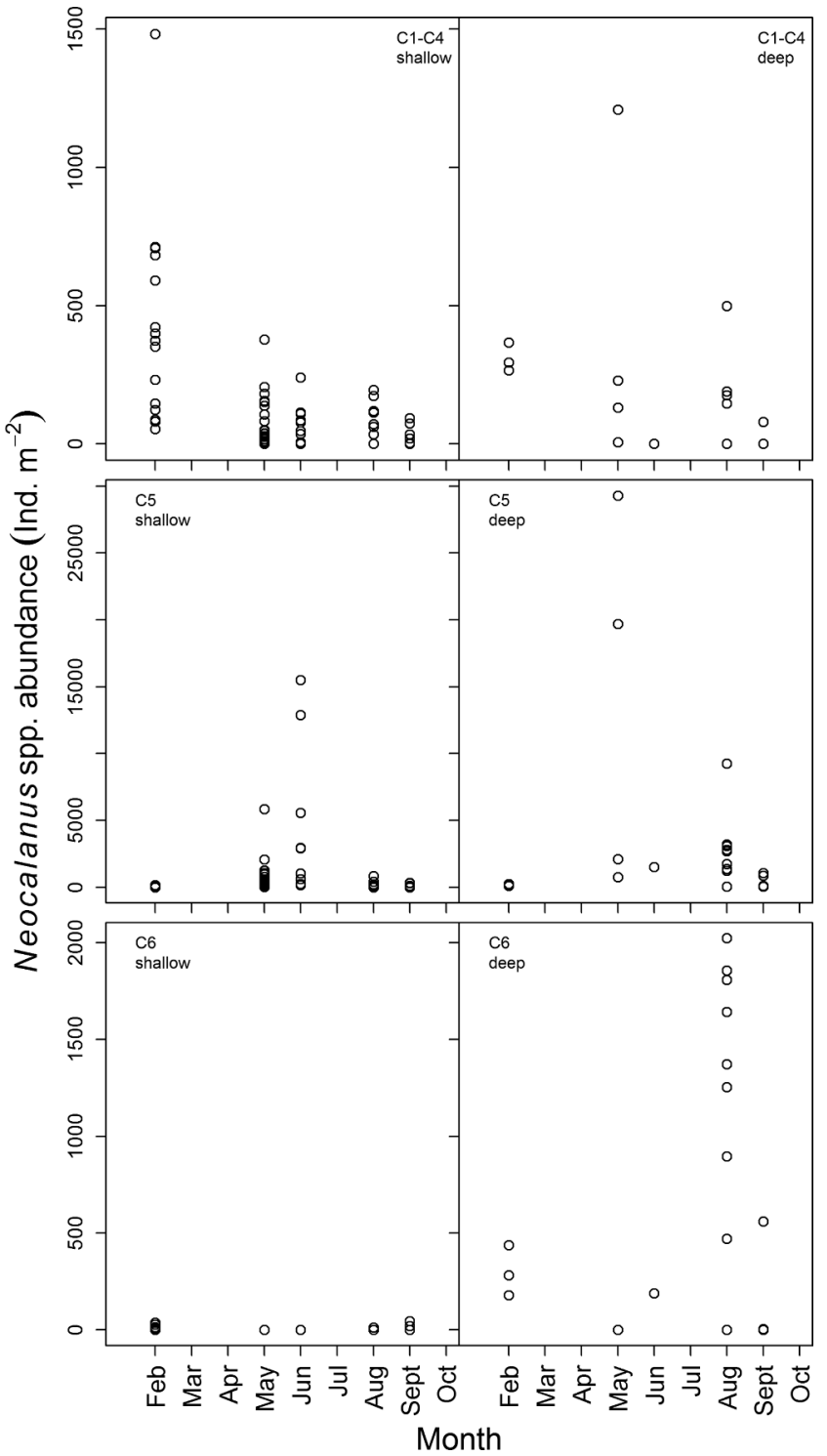

Fig. 10. Scatter plots illustrating the monthly abundance (pooled over 2011-2015) of Neocalanus spp.: (upper) juvenile (C1-C5); (middle) C5; and (lower) adult (C6) stages in shallow (left) and deep (right) net casts from Line $\mathrm{P}$ and La Perouse monitoring stations (refer to Fig. 1A and Section 2.5 of Methods - no samples are available for the months of March-April, July and OctoberDecember).

Barkley Canyon's seafloor between the 2013 and 2014 downward migration cycles, i.e., comparatively higher densities during the first summer, were corroborated by the net-tow cast data from Line P and La Perouse monitoring stations (Fig. 9-11), and could indicate a comparatively greater surface success experienced by C1-C4 stages translating into an earlier descent of C5 stages in the former year.

According to Mackas et al. (1998), a multidecadal analysis of the developmental timing of Neocalanus plumchrus at and near station Papa $\left(50.1^{\circ} \mathrm{N} ; 144.9^{\circ} \mathrm{W}\right)$ revealed that early developmental success and peak annual biomass at the surface shifted dramatically between 1956 and 1997. These changes were strongly correlated with large-scale year-toyear and decade-to-decade ocean climate fluctuations, as reflected by spring season temperature anomalies in the surface mixed layer. In short, during warmer years, the developmental timing and biomass (i.e., 50\% composed of C5 stages) peaks at surface occurred 60 days earlier than in cold years (i.e., from mid-May-early June). While our time series was not large enough to determine strong cause-effect
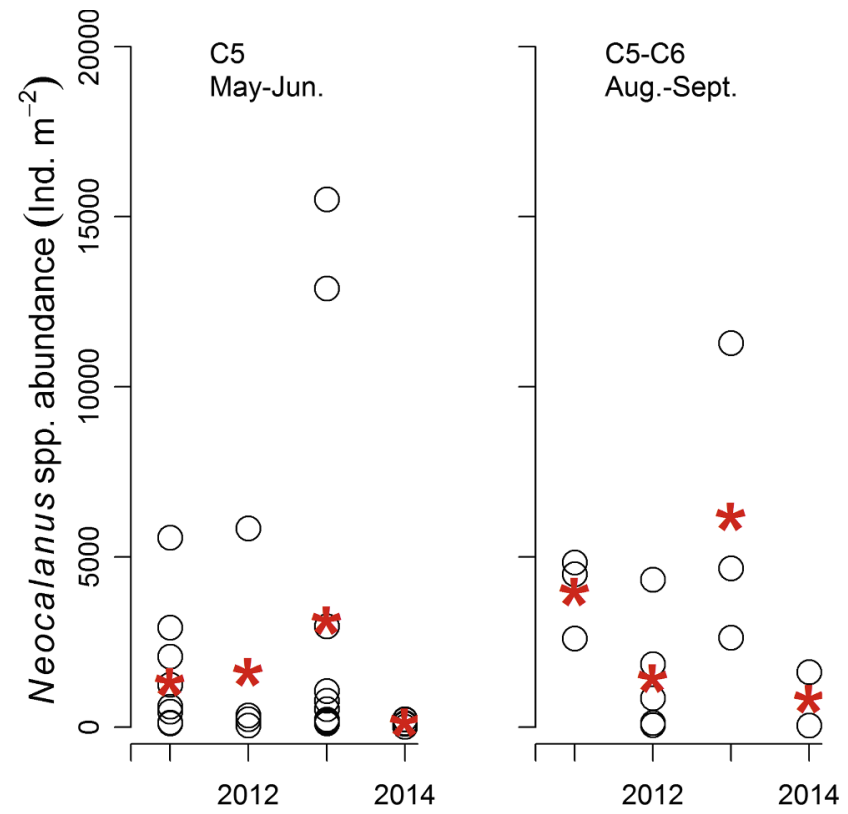

Fig. 11. Annual abundance of late stage Neocalanus spp. in deep (>1000 m) net casts from Line $\mathrm{P}$ and La Perouse monitoring stations (refer to Fig. 1A). Open symbols represent abundance (individuals $\mathrm{m}^{-2}$ ) of C5 in May/June in shallow casts ( $<250 \mathrm{~m}$; left panel) and the abundance of C5-C6 stages in August/September in deep casts (right panel). The red star symbols represent the annual means. (For interpretation of the references to color in this figure legend, the reader is referred to the web version of this article.)

relationships between the timing and strength in the downward migration of N. plumchrus in Barkley Canyon and the surface ocean climatology (i.e., not quite two complete years of data), it was, however, contained within a peculiar period marked by the onset of a large positive temperature anomaly in the NE Pacific (Bond et al., 2015; Dewey et al., 2015; Kintisch, 2015). The so-called 'warm Blob' temperature anomaly developed during the winter of 2013-2014, with the upper $\sim 100 \mathrm{~m}$ waters experiencing greater than $2.5^{\circ} \mathrm{C}$ anomalies that were 3 standard deviations higher relative to the average from 1981 to 2010, persisting through the end of 2015 (Peterson et al., 2017). Cascading effects onto NE Pacific's pelagic ecosystems were observed following the onset of the 'Blob'. Some of these effects included temporary polarward niche expansions of tropical marine mammal and fish species, significant reductions in primary productivity, and shifts in zooplankton (mostly copepods) community structure, from subarcticdominated to subtropical species (Galbraith et al., 2015; Cavole et al., 2016; Batten et al., 2018). However, most of these changes were most noticeable southward of $45^{\circ} \mathrm{N}$, and therefore no clear connection with our observations can be made at this point. A further examination of all archived high-frequency acoustic Doppler time-series data ( $\sim 9$ years to date), and additional video imagery onwards from Jan 2015, both from the NEPTUNE observatory, will help us to drawn more reliable inferences of causal relationships between interannual variability in Neocalanus spp. overwintering migration and surface ocean climatology.

\subsection{Physical circulation affecting deep-migrating zooplankton in Barkley canyon}

Barkley Canyon is located at the highly productive northern end of the California Current System, an eastern boundary current region which is subject to seasonally modulated coastal upwelling (Freeland and Denman, 1982). At the shallower depths of the canyon, coincident with the adjacent upper continental slope and shelf break, upwelling strongly affects primary productivity by helping to bring nutrients to 
the photic zone (e.g. Hickey, 1989; Ware and Thomson, 2005). However, near the seafloor at greater depths $(\sim 970 \mathrm{~m})$ of our Barkley Canyon Axis study site (BCA), the effects of upwelling do not directly affect the local circulation or the primary oceanic variables, temperature and salinity, as measured by the cabled observatory (Matabos et al., 2014; Orozco, 2015). The physical circulation dynamics at Barkley Canyon's head and shallower flanks (surface down to $450 \mathrm{~m}$ ) has been relatively well constrained in a coupled observational and modelling study (Allen et al., 2001). The same study also investigated the influence of Barkley Canyon's complex topographically-constrained flow dynamics on zooplankton abundances at various stations on the shelf edge and within the canyon axis and flanks. Their results indicated that weakly motile zooplankton species (i.e., excluding euphausiids) resided in the upper 50-m stratum with similar distributions (from both day and night cast samples) in and outside the canyon, indicating simple advection by the currents around the canyon. Deeper species inhabiting the $150-400 \mathrm{~m}$ depth stratum were displaced towards the head of the canyon, especially on the downstream flank of the canyon, where the deep flow upwells strongly, with currents peaking at $30 \mathrm{~cm} \mathrm{~s}^{-1}$. At this exact location, one of the highest concentrations of ontogenetic migrating species, in particular Neocalanus plumchrus, were observed, and the authors discussed the role of this deep upward flow bringing oceanic water up canyon along with $N$. plumchrus individuals. This species was also found in relatively high abundances at the deep up- and downstream canyon flank stations around $200 \mathrm{~m}$ of depth (Allen et al., 2001).

In contrast to what has been described for the upper Barkley Canyon circulation and its effects on zooplankton distribution and abundance, no information exists on the role that deep current flow structure in Barkley Canyon play in advecting and concentrating zooplankton biomass. In particular since, to the best of our knowledge, these are the first observations at very high temporal resolution of these mass deep migrating copepod aggregations in the canyon. Our $\sim 20$-month time series of current measurements in BCA, at $970 \mathrm{~m}$ of depth, provides a new contribution to our understanding of Barkley Canyon physical dynamics along its deep mid-canyon axis. Previously, only snapshot current data at BCA ranging from weeks to months were available, and mostly during upwelling events (Orozco, 2015). Our current measurements, coupled with the video imagery and acoustic Doppler backscatter data, offered a new insight of the potential role Barkley Canyon's deep circulation may be playing in the advection and concentration of Neocalaus spp. during its yearly seasonal diapause at depth. We therefore propose a conceptual model which predicts the sources and sinks of ontogenetically migrant nonfeeding C5s and C6s (adults) Neocalanus, and a mechanism for aggregating the overwintering biomass at intermediate depths in Barkley Canyon (Fig. 12).

While this is just an initial picture of what may be occurring at depth in Barkley Canyon, a very recent study on the distribution of sedimentary as well as bottom water particulate organic matter along the canyon provides further support to our proposed conceptual model (Campanyà-Llovet et al., this volume). Much higher concentrations of zooplankton-derived lipids (i.e, wax esters and steryl esters) were observed at mid canyon depths $(600-900 \mathrm{~m})$, coinciding with the core overwintering depth range for Neocalanus plumchrus established by Miller et al. (1984). While these zooplankton lipid biomarkers were absent from sediments shallower $(200-500 \mathrm{~m})$ and deeper $(2000 \mathrm{~m})$ in the canyon, they occurred in significant quantities in the near bottom water particulate organic matter at $400 \mathrm{~m}$. Additionally, at mid-canyon depths (600-1000), not only zooplankton lipid biomarkers but other organic matter proxies indicative of highly labile organic matter, such as high chlorophyll- $a$ /phaeopigment ratios (i.e., fresh phytodetritus), phospholipids (i.e, fresh phyto- and zooplankton cells) and EPA fatty acids (i.e, diatoms), all got deposited in higher quantities in what appears to be a 'hotspot' depositional centre within the entire canyon (Fig. 12D) (Campanyà-Llovet et al., this volume). This would mean lipid-rich dormant C5 Neocalanus spp. individuals are settling in the sedimentary environment at this particular 'hotspot' in the canyon axis. These observations appear to be supported by: (1) a deep along-canyon axis current, which seems to concentrate, via topographic confinement, and advect copepods and other fresh organic matter down canyon, and (2) by the up-canyon flow from between 78 and $300 \mathrm{~m}$ above the seabed, which may be acting as an entrapment cell retaining overwintering copepods at depth (Fig. 12D). In contrast, the higher hydrodynamism at the upper canyon ( $\leq 400 \mathrm{~m}$ from sea surface), with current velocities one magnitude higher in average (Allen et al., 2001), prevent settlement of C5 stages and dead adult Neocalanus spp., and may explain why the labile lipid signal may be only present in the near bottom water column but not in the seafloor sediments (CampanyàLlovet et al., this volume).

During spring and summer, Neocalanus spp. is still present at depth but in less pronounced densities (observed both on video and proxied by the Doppler data; Figs. 6 and 8), which may indicate late C5 cohorts still undergoing final maturing prior to reproduction (Fig. 12C). Although between-year variability did occur, with much higher densities for spring and summer of 2013 (as discussed in Section 4.1). Lastly, the apparent topographic effect concentrating Neocalanus spp. along the canyon axis (BCA) seems to be hampered by a different current regime in the canyon flank site (BCW), which is positioned in a slightly shallower $(\sim 100 \mathrm{~m})$ plateau situated at a $\sim 90^{\circ}$ corner of the canyon. Although located only about $1 \mathrm{~km}$ to the NW (Fig. 12C and D), the currents here are complicated by both the large scale turn in the direction of the canyon axis, the local bathymetry, and a plateau break in the much steeper canyon wall. Therefore, this suggests that in order to effectively use video imagery and high-frequency acoustic Doppler data to quantify migrant zooplankton biomass, the selection of an area in the canyon representative of its main flow is paramount. This is the case for our canyon axis site (BCA), which is representative of the thalweg of the canyon.

\subsection{Neocalanus ontogenetic migration, carbon flux and pelagic-benthic coupling at Barkley Canyon's deep seafloor}

The yearly mean contribution of Neocalanus plumchrus ontogenetic migration to the carbon flux into the mesopelagic zone in the eastern subarctic Pacific has been estimated in $5 \mathrm{~g} \mathrm{C} \mathrm{m}^{-2} \mathrm{yr}^{-1}$ (min. 1.44, max. $8.82 \mathrm{C} \mathrm{m}^{2} \mathrm{yr}^{-1}$ ), based on net tow sample data from Station Papa (Bradford-Grieve et al., 2001). These calculations are based on a 25-yr average of late summer wet weight biomass of $N$. plumchrus (Mackas et al., 1998) converted into carbon units by a functional regression equation (Weibe, 1988). It assumes that the carbon export due to seasonal vertical migration is approximately equivalent to $N$. plumchrus late summer biomass (largely C5 individuals), which is almost twice the mean annual sedimentary particulate organic carbon flux at Station Papa, i.e., $2.7 \mathrm{~g} \mathrm{C} \mathrm{m}^{2} \mathrm{yr}^{-1}$ (s.d. = 1.29; data from 1983 to 1993) (Bradford-Grieve et al., 2001). N. plumchrus estimated migratory carbon flux to depth also takes into consideration the respiratory carbon losses for the deep-residing populations and assumes that C6 males contribute with $100 \%$ of their body carbon mass to the flux, whereas C6 females contribute only with $32 \%$ after discounting egg production (Kobari et al., 2008a).

We estimated the areal coverage of Barkley Canyon's seafloor intersecting the core overwintering depth of Neocalanus spp. (i.e. $800-1100 \mathrm{~m}$ ), based both on our observations at BCA and BCW and on the lipid biomarker data contained in Campanyà-Llovet et al. (this volume), being equivalent to approximately $24 \mathrm{~km}^{2}$ along the canyon axis (measured from a 5-m grid resolution multibeam bathymetric data). Therefore, if we then extrapolate Neocalanus plumchurs carbon flux at depth due to its seasonal ontogenetic migration, an equivalent of 35-215 tons (mean 122 tons) of carbon may be reaching this labile organic-rich 'hotspot' in Barkley Canyon's seafloor each year. Furthermore, rapid winter downwelling-triggered POC flux pulses (largely phytodetritus) have also recently being reported to be deposited in 


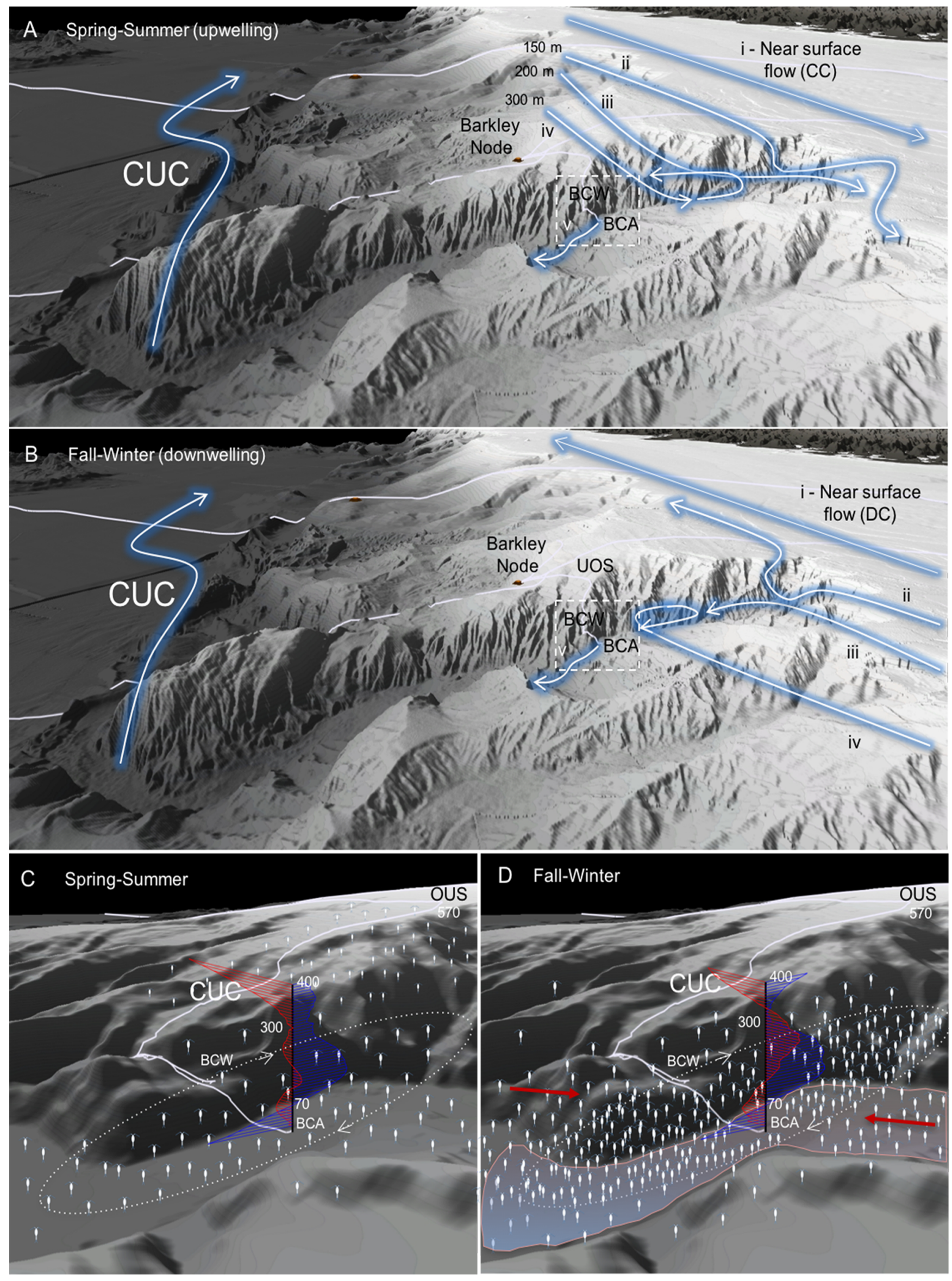




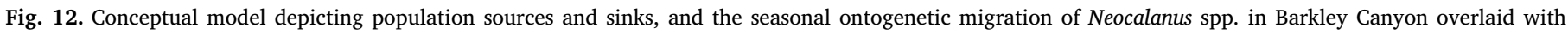

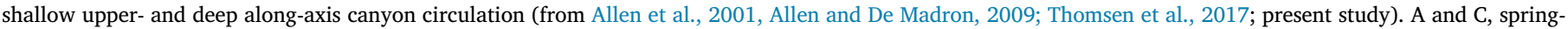

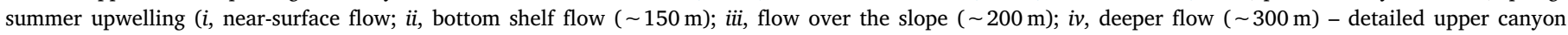

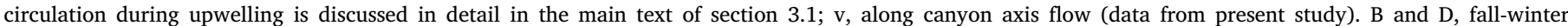

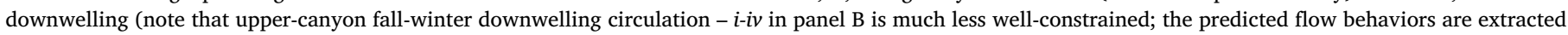

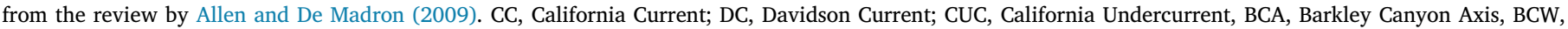

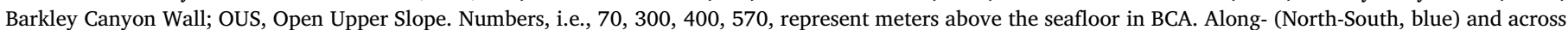

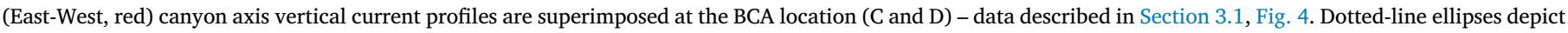

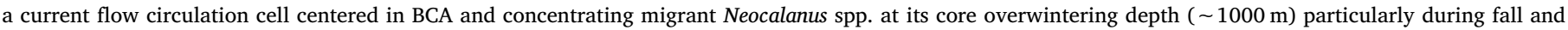

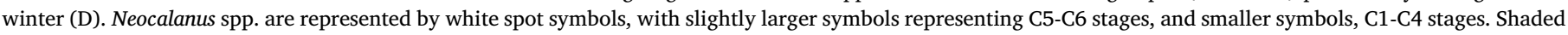

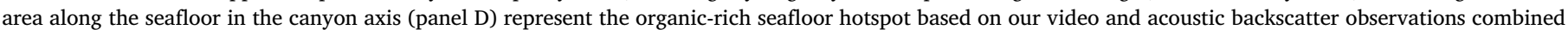

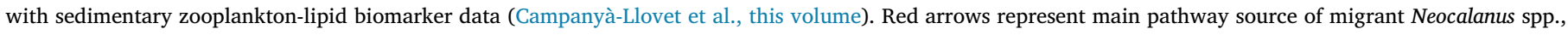

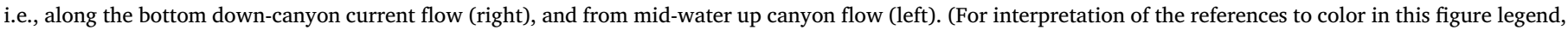
the reader is referred to the web version of this article.)

bottom sediments at BCA and BCW sites, with a rapid response in activity by megabenthic communities, in particular the detritivore tanner crab Chionoecetes tanneri, and the bottom feeder sablefish Anoplopoma fimbria (Thomsen et al., 2017). These winter POC pulses reach the seafloor ( $870 \mathrm{~m}$ at $\mathrm{BCW}$ ) as quickly as $12-72 \mathrm{~h}$ following chlorophyll-a peaks at surface (estimated from MODIS ocean colour satellite data), and upper canyon-rim eddies (cyclonic and anticyclonic) promoting strong downwelling currents are described as the main transport mechanism (Thomsen et al., 2017).

This organic-rich seafloor hotspot appears, however, to be only partially exploited by the smaller body-sized macrobenthic communities, as this area in the canyon intersects the core of the oxygen minimum zone (Juniper et al., 2013; De Leo et al., 2017), which has reported low macrobenthic diversity and abundance (Campanyà-Llovet et al., this volume), and relatively low sediment-water nutrient fluxes and benthic community oxygen uptake (Belley et al., 2016). Future investigations of the long-term interannual variability in the ontogenetic migration of Neocalanus spp. will provide new insights into the role of this organic-enrichment hotspot on the ecosystem function, carbon sequestration, and pelagic-benthic coupling in Barkley Canyon. In addition, these future studies could also be designed to shed light on the role of this deep migrant carbon export flux on local mesopelagic food-webs, in particular since ontogenetically migrating copepods are of extreme importance in the diets of biomass-dominant myctophids (Kobari et al., 2008b).

Lastly, we might consider a topographic 'canyon effect' in the accumulation of this organic-rich hotspot, as similarly reported for other productive canyon systems (Tyler et al., 2009; De Leo et al., 2010; Pusceddu et al., 2010; Amaro et al., 2015). There are at least 230 additional submarine canyons from the southern tip of Vancouver Island towards the tip of the gulf of Alaska (Harris et al., 2014a), where large subarctic ontogenetically migrating calanoid copepods dominate the total zooplankton biomass (Goldblatt et al., 1999; Mackas and Tsuda, 1999; Mackas and Coyle, 2005). Thus, a several orders-of-magnitude greater carbon flux and sequestration at depth due to deep ontogenetic migrant zooplankton should be expected for the entire continental margin in the subarctic NE Pacific.

\section{Conclusions}

We conclude that the high-frequency observations made possible by a seafloor cabled observatory offered an entirely novel approach for monitoring the seasonal and interannual variability in the deep water biomass of large ontogenetically migrating calanoid copepods, a key zooplankton functional group for the subarctic NE Pacific pelagic foodweb. Previously, the developmental and reproductive cycle, migratory biomass and export flux by Neocalanus spp. (more comprehensively $N$. plumchrus, $N$. cristatus, $N$. flemingeri) were only investigated by means of limited temporally discrete sampling by the Line $\mathrm{P}$ and La Perouse Bank monitoring programs. The high-resolution nature of the data streams provided by the observatory allowed us to examine the precise timing of the downward seasonal migration of Neocalanus spp. and therefore a detailed investigation of its interannual variability is now possible. Since the early developmental success and resulting downward migratory biomass of Neocalanus is strongly coupled with surface ocean climatology, a further look at the entire archived high resolution data of seafloor high-frequency acoustic Doppler backscatter from the NEPTUNE observatory ( $\sim 9$ years of data) will offer an unique opportunity to look at seasonal and interannual variability that may emerge in response to the ongoing long-term sea surface warming taking place in the NE Pacific and its effects in the carbon flux and sequestration at depth.

\section{Acknowledgements}

We would like to thank Ocean Networks Canada's Marine Operations team for onshore and at-sea support and maintenance of the NEPTUNE cabled observatory. We also extend our gratitude to ONC's 'Data' and 'Data Stewardship' teams for ensuring data quality and curation of all observatory data streams utilized in this study. Special thanks to K. Douglas, in charge of curating ONC's multibeam bathymetric database, who prepared Fig. 1 and 3D base maps for Fig. 12. We thank the Department of Fisheries and Oceans (DFO) and the Institute of Ocean Sciences (IOS), in Sidney, BC, Canada, for providing the 5-yr net tow data from Line P and La Perouse monitoring stations. B. Ogata received grants from Ministry of Education 'CAPES-Science Without Borders Program' and from University of Victoria's Department of Biology Co-op program. Ocean Networks Canada is a non-profit initiative of University of Victoria, funded primarily by Canada Foundation for Innovation. All data streams from ONC's observatories are freely available online through 'Oceans 2.0' data archive and management system (https://data.oceannetworks.ca). Finally, we thank Pere Puig and two anonymous reviewers who helped to substantially enhance the quality of the final manuscript.

\section{Appendix A. Supplementary material}

Supplementary data associated with this article can be found, in the online version, at https://doi.org/10.1016/j.pocean.2018.06.001.

\section{References}

Allen, S.E., De Madron, X.D., 2009. A review of the role of submarine canyons in deepocean exchange with the shelf. Ocean Sci. 5, 607-620.

Allen, S.E., Vindeirinho, C., Thomson, R.E., Foreman, M.G.G., Mackas, D.L., 2001 Physical and biological processes over a submarine canyon during an upwelling event. Can. J. Fish. Aquat. Sci. 58, 671-684. https://doi.org/10.1139/f01-008.

Amaro, T., de Stigter, H., Lavaleye, M., Duineveld, G., 2015. Organic matter enrichment in the Whittard Channel; its origin and possible effects on benthic megafauna. DeepSea Res. Part I 102, 90-100. https://doi.org/10.1016/j.dsr.2015.04.014.

Aslam, T., Hall, R., Dye, S.R., 2018. Internal tides in a dendritic submarine canyon. Prog. Oceanogr. https://doi.org/10.1016/j.pocean.2017.10.005. (this volume).

Baker, E.T., Hickey, B.M., 1986. Contemporary sedimentation processes in and around an active west coast submarine canyon. Mar. Geol. 71, 15-34.

Barnes, C.R., Best, M.M., Johnson, F.R., Pirenne, B., 2010. Final installation and initial 
operation of the world's first regional cabled ocean observatory (NEPTUNE Canada). Can. Met. Ocean. Soc. 38 (3), 89-96.

Batten, S.D., Raitsos, D.E., Danielson, S., Hopcroft, R., Coyle, K., McQuatters-Gollop, A., 2018. Interannual variability in lower trophic levels on the Alaskan Shelf. Deep-Sea Res. II 147, 58-68. https://doi.org/10.1016/j.dsr2.2017.04.023.

Belley, R., Snelgrove, P.V.R., Archambault, P., Juniper, S.K., 2016. Environmental drivers of benthic flux variation and ecosystem functioning in salish sea and northeast pacific sediments. Plos-One. https://doi.org/10.1371/journal.pone.0151110.

Bond, N.A., Cronin, M.F., Freeland, H., Mantua, N., 2015. Causes and impacts of the 2014 warm anomaly in the NE Pacific. Geophys. Res. Lett. 42, 3414-3420. https://doi.org/ 10.1002/2015GL063306.

Bradford-Grieve, J.M., Nodder, S.D., Jillett, K.B., Currie, K., Lassey, K.R., 2001. Potential contribution that the copepod Neocalanus tonsus makes to downward carbon flux in the Southern Ocean. J. Plankton Res. 23, 963-975. https://doi.org/10.1093/plankt/ 23.9.963.

Burgner, R.L., 1991. Life history of sockeye salmon (Oncorhynchus nerka). In: Groot, C., Margolis, L. (Eds.), Pacific salmon life histories. University of British Columbia Press, Vancouver, B.C.

Campanyà-Llovet, N., Snelgrove, P.V.A., De Leo, F.C. (in press). Food quantity and quality in Barkley Canyon (NE Pacific) and its influence on macroinfaunal community structure. 10.1016/j.pocean.2018.04.003 (this volume).

Cavole, L.M., Demko, A.M., Diner, R.E., Giddings, A., et al., 2016. Biological impacts of the 2013-2015 warm-water anomaly in the Northeast Pacific. Oceanography 29 (2), 273-285. http://www.jstor.org/stable/24862690.

Chatzievangelou, D., Doya, C., Thomsen, L., Purser, A., Aguzzi, J., 2016. High-frequency patterns in the abundance of benthic species near a cold-seep - an internet operated vehicle application. Plos One 11 (10), e0163808. https://doi.org/10.1371/journal. pone. 0163808 .

Dagg, M.J., 1993. Sinking particles as a possible source of nutrition for the large calanoid copepod Neocalanus cristatus in the Subarctic Pacific Ocean. Deep-Sea Res. 40, 1431-1445.

De Leo, F.C., Gauthier, M., Nephin, J., Mihály, S., Juniper, S.K., 2017. Bottom trawling and oxygen minimum zone influences on continental slope benthic community structure off Vancouver Island (NE Pacific). Deep-Sea Res. II 137, 404-419. https:// doi.org/10.1016/j.dsr2.2016.11.014.

De Leo, F.C., Vetter, E.W., Smith, C.R., Rowden, A.A., McGranaghan, M., 2014. Spatial scale-dependent habitat heterogeneity influences submarine canyon macrofaunal abundance and diversity off the Main and Northwest Hawaiian Islands. Deep-Sea Res. II 104, 267-290. https://doi.org/10.1016/j.dsr2.2013.06.015.

De Leo, F.C., Drazen, J.C., Vetter, E.W., Rowden, A.A., Smith, C.R., 2012. The effects of submarine canyons and the oxygen minimum zone on deep-sea fish communities off Hawaii. Deep-Sea Res. I 64, 54-70. https://doi.org/10.1016/j.dsr.2012.01.014.

De Leo, F.C., Smith, C.R., Rowden, A., Bowden, D., Clark, M., 2010. Submarine canyons: hotspots of benthic biomass and productivity in the deep sea. Proc. Roy. Soc. Lon. B 277, 2783-2792. https://doi.org/10.1098/rspb.2010.0462.

Dewey, R., Sastri, A., Mihály, S., 2015. The 2014 perspective from Ocean Networks Canada. In: Chandler, P.C., King, S.A., Perry, R.I., (Eds.). State of the physical, biological and selected fishery resources of Pacific Canadian marine ecosystems in 2014. Can. Tech. Rep. Fish. Aquat. Sci. 3131: vi + 211 p.

Domke, L., Lacharité, M., Metaxas, A., Matabos, M. (in press). Influence of an oxygen minimum zone and macroalgal enrichment on benthic megafaunal community composition in a NE Pacific submarine canyon. Mar. Ecol. 10.1111/maec.12481.

Freeland, H.J., Denman, K.L., 1982. A topographically upwelling center off southern Vancouver Island. J. Mar. Res. 40 (4), 1069-1093.

Galbraith, M., Mackas, D., Young. K., 2015. Zooplankton along the B.C. continental margin 2014, and the impacts of warm off shelf waters. In: Chandler, P.C., King, S.A., and Perry, R.I. (Eds.). State of the physical, biological and selected fishery resources of Pacific in 2014. Can. Tech. Rep. Fish. Aquat. Sci. 3131, 85-92.

Genin, A., 2004. Bio-physical coupling in the formation of zooplankton and fish aggregations over abrupt topographies. J. Mar. Syst. 50, 3-20. https://doi.org/10. 1016/j.jmarsys.2003.10.008.

Gifford, D.J., 1993. Protozoa in the diets of Neocalanus spp. in the oceanic Subarctic Pacific Ocean. Prog. Oceanogr. 32, 223-237.

Goldblatt, R.H., Mackas, D.L., Lewis, A.G., 1999. Mesozooplankton community characteristics in the NE subarctic Pacific. Deep-Sea Res. II 46, 2619-2644. https://doi. org/10.1016/S0967-0645(99)00078-8.

Greene, C.H., Wiebe, P.H., Burkczynski, J., Youngbluth, M.J., 1988. Acoustical detection of high-density krill demersal layers in the submarine canyon off Georges Bank. Science 241, 359-361.

Harris, P.T., Macmillan-Lawler, M., Rupp, J., Baker, E.K., 2014a. Geomorphology of the oceans. Mar. Geol. 352, 4-24. https://doi.org/10.1016/j.margeo.2014.01.011.

Harris, P.T., J. Barrie, J.V., Conway, K.W., Greene, H.G., 2014b. Hanging canyons of Haida Gwaii, British Columbia, Canada: Fault-control on submarine canyon geomorphology along active continental margins. Deep-Sea Res. II 104, 83-92. https:// doi.org/10.1016/j.dsr2.2013.06.017.

Haugerud, R.A., 1999. Digital elevation model (DEM) of Cascadia, latitude 39N-53N, longitude 116W-133W. U.S. Geological Survey Open-File Report 99-369, < https:// pubs.usgs.gov/of/1999/0369/>

Hickey, B.M., 1997. The response of a steep-sided narrow canyon to strong wind forcing. J. Phys. Oceanogr. 27, 697-726. https://doi.org/10.1175/1520-0485(1997) $027<0697$ :TROASS $>2.0$.CO;2.

Hickey, B.M., 1989. Patterns and processes of circulation over the shelf and slope. In: Landry, M.R., Hickey, B.M. (Eds.), Coastal Oceanography of Washington and Oregon, Elsevier, New York, pp. 41-109.

Hooker, S., Whitehead, H., Gowans, S., 1999. Marine protected area design and the spatial and temporal distribution of cetaceans in a submarine canyon. Conserv. Biol.
13 (3), 592-602. https://doi.org/10.1046/j.1523-1739.1999.98099.x.

Hunt, G.L., Harrison, N.M., Piatt, J.F., 1993. Foraging ecology as related to the distribution of planktivorous auklets in the Bering Sea. In: Vermeer, K., Briggs, K.T., Morgan, K.H., Siegel-Causey, D. (Eds.), The status, ecology, and conservation of marine birds of the North Pacific. Can. Wildl. Serv. Spec. Publ. pp. 18-26.

Juniper, S.K., Matabos, M., Mihály, S., Ajayamohan, R., Gervais, F., Bui, A., 2013. A year in Barkley Canyon: a time-series observatory study of mid-slope benthos and habitat dynamics using the NEPTUNE Canada network. Deep-Sea Res. II 92, 114-123. https://doi.org/10.1016/j.dsr2.2013.03.038.

Kawamura, A., 1982. Food habits and prey distributions of three rorqual species in the North Pacific Ocean. Sci. Rep. Whales Res. Inst. 34, 59-91.

Kawamura, A., Fujii, F., 1988. Forage of the mesopelagic fishes, Symbolophorus californiensis (Egenmann \& Eigenmann) and Tarletonbeania tailori Mead caught in gillnets in the northwestern North Pacific Ocean. Bull. Ocean Res. Inst. Tokyo 26, 143-159.

Kintisch, E., 2015. The 'Blob' invades Pacific, flummoxing climate experts. Science 348 (6230), 17-18. https://doi.org/10.1126/science.348.6230.17.

Klinck, J.M., 1996. Circulation near submarine canyons: a modeling study. J. Geophys. Res. 101, 1211-1223. https://doi.org/10.1029/95JC02901.

Kobari, T., Shinada, A., Tsuda, A., 2003. Functional roles of interzonal migrating mesozooplankton in the western subarctic Pacific. Prog. Oceanogr. 57, 279-298. https:// doi.org/10.1016/S0079-6611(03)00102-2.

Kobari, T., Steinberg, D.K., Ueda, A., Tsuda, A., Silver, M.W., Kitamura, M., 2008a. Impacts of ontogenetically migrating copepods on downward carbon flux in the western subarctic Pacific Ocean. Deep-Sea Res. II 55, 1648-1660. https://doi.org/10. 1016/j.dsr2.2008.04.016.

Kobari, T., Moku, M., Takahashi, K., 2008b. Seasonal appearance of expatriated boreal copepods in the Oyashio-Kuroshio mixed region. ICES J. Mar. Sci. 65, 469-476.

Lavoie, D., Simard, Y., Saucier, F.J., 2000. Aggregation and dispersion of krill at channel heads and shelf edges: the dynamics in the Saguenay-St. Lawrence Marine Park. Can. J. Fish. Aquat. Sci. 57, 1853-1869. https://doi.org/10.1139/f00-138.

Mackas, D.L., 1992. Seasonal cycle of zooplankton off southwestern British Columbia: 1979-89. Can. J. Fish. Aquat. Sci. 49 (5), 903-921. https://doi.org/10.1139/f92-101.

Mackas, D.L., Coyle, K.O., 2005. Shelf-offshore exchange processes, and their effects on mesozooplankton biomass and community composition patterns in the northeast Pacific. Deep-Sea Res. II 52 (5-7), 707-725. https://doi.org/10.1016/j.dsr2.2004.12. 020 .

Mackas, D.L., Tsuda, A., 1999. Mesozooplankton in the eastern and western subarctic Pacific: community structure, seasonal life histories, and interannual variability. Prog. Oceanogr. 43 (2-4), 335-363. https://doi.org/10.1016/S0079-6611(99) 00012-9.

Mackas, D.L., Kieser, R., Saunders, M., Yelland, D.R., Brown, R.M., Moore, D.F., 1997 Aggregation of euphausiids and Pacific hake (Merluccius productus) along the outer continental shelf off Vancouver Island. Can. J. Fish. Aquat. Sci. 54, 2080-2096. https://doi.org/10.1139/f97-113.

Mackas, D.L., Goldblatt, R., Lewis, A.L., 1998. Interdecadal variation in developmental timing of Neocalanus plumchrus populations at Ocean Station P in the subarctic North Pacific. Can. J. Fish. Aquat. Sci. 55, 1878-1893. https://doi.org/10.1139/f98-080.

Mackas, D.L., Thomson, R.E., Galbraith, M., 2001. Changes in the zooplankton community of the British Columbia continental margin, 1985-1999, and their covariation with oceanographic conditions. Can. J. Fish. Aquat. Sci.58 (4), 685-702. https://doi. org/10.1139/f01-009.

Macquart-Moulin, C., Patriti, G., 1996. Accumulation of migratory micronekton crustaceans over the upper slope and submarine canyons of the northwestern Mediterranean. Deep-Sea Res. I 43 (5), 579-601. https://doi.org/10.1016/09670637(96)00039-8.

Matabos, M., Bui, A.O.V., Mihály, S., Aguzzi, J., Juniper, S.K., Ajayamohan, R.S., 2014. High-frequency study of epibenthic megafaunal community dynamics in Barkley Canyon: a multi-disciplinary approach using the NEPTUNE Canada network. J. Mar. Sys. 130, 56-68. https://doi.org/10.1016/j.jmarsys.2013.05.002.

McClain, C.R., Barry, J.P., 2010. Habitat heterogeneity, disturbance, and productivity work in concert to regulate biodiversity in deep submarine canyons. Ecology 91, 964-997. https://doi.org/10.1890/09-0087.1.

Miller, C.B., Clemons, M., 1988. Revised life history analysis for large grazing copepods in the subarctic Pacific Ocean. Prog. Oceanogr. 20, 293-313. https://doi.org/10.1016/ 0079-6611(88)90044-4.

Miller, C.B., Frost, B.W., Batchelder, H.P., Clemons, M.J., Conway, R.E., 1984. Life histories of large, grazing copepods in a subarctic ocean gyre: Neocalanus plumchrus, Neocalanus cristatus, and Eucalanus bungii in the Northeast Pacific. Prog. Oceanogr. 13, 201-243. https://doi.org/10.1016/0079-6611(84)90009-0.

Moors-Murphy, H.B., 2014. Submarine canyons as important habitat for cetaceans, with special reference to the Gully: a review. Deep-Sea Res. II 104, 6-19. https://doi.org/ 10.1016/j.dsr2.2013.12.016.

Ocean Networks Canada Data Archive, 2013. A 5-min video segment recorded from Barkley Canyon Axis' (970 m depth) video camera on December 15, 2013, at 10:01:00 UTC. https://data.oceannetworks.ca/SeaTube?resourceTypeId =1000\& resourceId $=231528$ diveId $=9800414 \&$ time $=2013-12-15 \mathrm{~T} 10: 01: 00.000 Z$

Oliveira, A., Santos, A.I., Rodrigues, A., Vitorino, J., 2007. Sedimentary particle distribution and dynamics on the Nazaré canyon system and adjacent shelf (Portugal). Mar. Geol. 246, 144-164. https://doi.org/10.1016/j.margeo.2007.04.017.

Orozco, P.M.S., 2015. Investigation into Summertime 2013 Wind-driven Upwelling/ Downwelling Events in Barkley Canyon, Canada. BSc Honours Thesis, Federal University of Rio Grande, RS, Brazil. 33 p.

Paull, C., 2017. Data set acquired with a Reson SeaBat 7125 Multibeam Sonar on AUV D. Allan B. as part of data compilation BarkleyCanyon_Paull conducted in 2006 (Chief Scientist: Dr. Charles Paull, Investigator: Dr. Charles Paull). doi: 10.1594/IEDA/ 324052 . 
Paull, C.K., Greene, H.G., Ussler III, W., Mitts, P.J., 2002. Pesticides as tracers of sediment transport through Monterey Canyon. Geo-Mar. Lett. 22, 121-126. https://doi.org/10. 1007/s00367-002-0110-1.

Peterson, W.T., Fisher, J.L., Strub, P.T., Du, X., Risien, C., Peterson, J., Shaw, C.T., 2017. The pelagic ecosystem in the Northern California Current off Oregon during the 2014-2016 warm anomalies within the context if the past 20 years. J. Geophys. Res. Oceans 122 7767-7290.

Puig, P., Palanques, A., Martín, J., 2014. Contemporary sediment-transport processes in submarine canyons. Ann. Rev. Mar. Sci. 6, 53-77. https://doi.org/10.1146/annurevmarine-010213-135037.

Pusceddu, A., Bianchelli, S., Canals, M., Sanchez-Vidal, A., De Madron, A.D., et al., 2010. Organic matter in sediments of canyons and open slopes of the Portuguese, Catalan, Southern Adriatic and Cretan Sea margins. Deep-Sea Res. I 57 (3), 441-457. https:// doi.org/10.1016/j.dsr.2009.11.008.

Rasband, W.S., 2009 IMAGE J. US National Institutes of Health, Bethesda, MD. See $<$ http://rsb.info.nih.gov/ij/ > .

Robert, K., Juniper, S.K., 2012. Surface-sediment bioturbation quantified with cameras on the NEPTUNE Canada cabled observatory. Mar. Ecol. Prog. Ser. 453, 137-149. https://doi.org/10.3354/meps09623.

Ryan, J.P., Chave, F.P., Bellingham, J.G., 2005. Physical-biological coupling in Monterey Bay, California: topographic influences on phytoplankton ecology. Mar. Ecol. Prog. Ser. 287, 23-32. http://www.jstor.org/stable/24869009.

Ryan, W.B.F., Carbotte, S.M., Coplan, J.O., O'Hara, Melkonian, A., et al., 2009. Global multi-resolution topography synthesis. Geochem. Geophys. Geosyst. 10, Q03014. https://doi.org/10.1029/2008GC002332.

Schlacher, T.A., Schlacher-Hoenlinger, M.A., Williams, A., Althaus, F., Hooper, J.N.A., Kloser, R., 2007. Richness and distribution of sponge megabenthos in continental margin canyons off southeastern Australia. Mar. Ecol. Prog. Ser. 340, 73-88. http:// www.jstor.org/stable/24871802.

Schlining, K., von Thun, S., Kuhnz, L., Schlining, B., Lundsten, L., Stout, N.J., Chaney, L., Connor, J., 2013. Debris in the deep: using a 22-year video annotation database to survey marine litter in Monterey Canyon, central California. USA. Deep-Sea Res. I 79, 96-105. https://doi.org/10.1016/j.dsr.2013.05.006.

Seabrook, S., De Leo, F.C., Baumberger, T., Raineault, N., Thurber, A.R., 2017. Heterogeneity of methane seep biomes in the Northeast Pacific. Deep-Sea Res. II. https://doi.org/10.1016/j.dsr2.2017.10.016. Available online 8 November, 2017.
Sobarzo, M., Figueroa, M., Djurfeldt, L., 2001. Upwelling of subsurface water into the rim of the Biobio submarine canyon as a response to surface winds. Cont. Shelf Res. 21, 279-299. https://doi.org/10.1016/S0278-4343(00)00082-0.

Steinberg, D.K., Van Moy, B.A.S., Buesseler, K.O., Boyd, P.W., Kobari, T., Karl, D.M., 2008. Bacterial vs. zooplankton control of sinking particle flux in the ocean's twilight zone. Limnol. Oceanogr. 53 (4), 1327-1338. https://doi.org/10.4319/1o.2008.53.4. 1327.

Thomson, R.E., Krassovski, M.V., 2010. Poleward reach of the California Undercurrent extension. J. Geophys. Res. 115, C9. https://doi.org/10.1029/2010JC006280.

Thomsen, L., Aguzzi, J., Costa, F.C., De Leo, F.C., Ogston, A., Purser, A., 2017. The oceanic biological pump: rapid carbon transfer to depth at continental margins during winter. Sci. Reports 7, 10763. https://doi.org/10.1038/s41598-017-11075-6.

Tomita, M., Ikeda, T., Shiga, N., 1999. Production of Oikopleura longicauda (Tunicata: Appendicularia) in Toyama Bay, southern Japan Sea. J. Plank. Res. 21, 2412-2430. https://doi.org/10.1093/plankt/21.12.2421.

Tyler, P.A., Amaro, T., Arzola, R., Cunha, M.R., de Stigter, H., et al., 2009. Europe's Grand Canyon: Nazaré submarine canyon. Oceanography 22, 46-57.

Vetter, E.W., Dayton, P.K., 1998. Macrofaunal communities within and adjacent to a detritus-rich submarine canyon. Deep-Sea Res. II 45, 25-54. https://doi.org/10. 1016/S0967-0645(97)00048-9.

Vetter, E.W., Dayton, P.K., 1999. Organic enrichment by macrophyte detritus, and abundance patterns of megafaunal populations in submarine canyons. Mar. Ecol. Prog. Ser. 186, 137-148. http://www.jstor.org/stable/24853300.

Vetter, E.W., Smith, C.R., De Leo, F.C., 2010. Hawaiian hotspots: enhanced mega-faunal abundance and diversity in submarine canyons on the oceanic islands of Hawaii. Mar. Ecol. 31, 183-199. https://doi.org/10.1111/j.1439-0485.2009.00351.x.

Ware, D.M., Thomson, R.E., 2005. Bottom-up ecosystem trophic dynamics determine fish production in the northeast Pacific. Science 308, 1280-1284. https://doi.org/10. 1126/science.1109049.

Weibe, P.H., 1988. Functional regression equations for zooplankton displacement volume, wet weight, dry weight, and carbon: a correction. Fish. Bull. 86, 833-835.

Widder, E.A., Robison, B.H., Reisenbichler, K.R., Haddock, S.H.D., 2005. Using red light for in situ observations of deep-sea fishes. Deep-Sea Res. II 52, 2077-2085.

Zhao, Z., Alford, M., Lien, R.C., Gregg, M.C., Carter, G., 2012. Internal tides and mixing in a submarine canyon with time-varying stratification. J. Phys. Oceanogr 42 , 2121-2142. https://doi.org/10.1175/JPO-D-12-045.1. 